\begin{tabular}{|c|c|c|}
\hline $\begin{array}{l}\text { FATIH } \\
\text { SULTAN } \\
\text { MEHMET } \\
\text { VAKIF UUNIVESIITESI } \\
2010\end{array}$ & $\begin{array}{l}\text { FSM İlmî Araştırmalar Insan ve Toplum Bilimleri Dergisi } \\
\text { FSM Scholarly Studies Journal of Humanities and Social Sciences } \\
\text { Sayı/Number } 14 \text { Yıl/Year } 2019 \text { Güz/Autumn } \\
\text { (C2019 Fatih Sultan Mehmet Vakıf Üniversitesi }\end{array}$ & 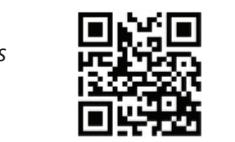 \\
\hline DOI: & http://dergipark.org.tr/fsmia & http://dergi.fsm.edu.tr \\
\hline Araştırma Makalesi / Research Article & Geliş Tarihi / Received: 30.04.2019 Kabul Tarihi / Accepted: 12.06.2019 & FSMIAD, 2019; (14): 481-526 \\
\hline
\end{tabular}

\title{
Fıkıh ve Şeriat Kavramları Bağlamında İslam Fıkhının Beşeriliği Konusu
}

Hidayet Zertürk ${ }^{*}$

\section{Öz}

Vahiy, yeryüzünde insanı muhatap almakla onun bulunduğu şartları ve yaşam dinamiklerini elbette gözetmektedir. Bu durum, onu ilahilikten beşeriliğe indirgemeyi gerektirecek bir argüman olarak değerlendirilemez. Aslında beşer, telakki ettiği vahiy ile Allah'ın çizdiği bir yola kendi iradesiyle girme kararını vermiş oluyor. Vahyin tamamı din, devamlılık süreci şeriat, zaman ve şartlara göre uygulanışı ise fikıh olarak adlandırılırsa da temelde şeriat, dinden ayrı olmadığı gibi; fikıh da şeiâtten ayrı tasavvur edilemez. Zira fikıh ancak şeriatten kaynaklanma şartıyla bağlayıcı olma özelliği taşır. Şunu da ilave edelim ki fikıh, şeriatın evrensellik boyutunu beşeri algıya sunma konusunda bir aracı mesabesindedir.

Anahtar Kelimeler: İlahilik, beşerilik, vahiy, fikıh, şeriat.

* Doktora Öğrencisi, Fatih Sultan Mehmet Vakıf Üniversitesi Lisansüstü Eğitim Enstitüsü Temel İslam Bilimleri, hidayetsadik@hotmail.com, İstanbul/Türkiye, orcid.org/0000-00018252-8949 


\title{
The Human Nature Problem of Islamic Fiqh According to the Context of Fiqh and Shariah
}

\begin{abstract}
Revelation certainly pays regard to the life dynamics and conditions of human by addressing him. This would not be evaluated as an argument that necessitates degrading it from divine nature to human nature. In fact, human decides to enter a way that is chosen by Allah with the revelation he accepts. Although the complete form of the revelation is called as religion, its continuity process is called as shariah and its practice according to the time and conditions is called fiqh, shariah is not seperate from religion like fiqh can't be accepted as seperate from shariah because fiqh becomes binding only if it results from the shariah. In addition, we say that fiqh is a vehicle that presents universal side of the shariah to human perception.
\end{abstract}

Keywords: Divine nature, human nature, revelation, fiqh, shariah. 


\section{Giriş}

"Fıkıh" ve "şeirat" kavramları, delâlet ettikleri anlam ve ifade ettikleri maksat açısından uzun araştırmalara konu oldukları gibi, bu ikisi arasındaki ilişki de farklı boyutlarda tartışılmıştır. Bunların, bazen birbiri yerinde kullanılması ile nassı yorumlama ameliyyesi olan ictihadın gerekliliği, her iki kavramı devamlı bir ilişki üzere olmaya zorlamıştır. Buna ilave olarak her iki kavramın tarihi süreç içerisinde kazandıkları delâlet boyutları, anlamın belirlenmesinde etkili olmuştur.

Sözü edilen kavramların sözlük ve işlevsellik alanları farklı algı türleriyle yorumlanarak İslam fıkhı'nın beşeriliği ve dolayısıyla bunun, beşeri hukuktan pek ayrı tutulamayacağı ileri sürülmüştür. ${ }^{1}$ Tabi ki bu anlayışa iten âmillerin başında, ictihattan kaynaklanan mezhep ihtilafları bulunmaktadır. İhtilafların birbiriyle çelişki oluşturacak noktalara varması ve bazen de nassın ruhundan ayrı düşmesi durumları, bu anlayışı ister istemez cesaretlendirmiştir. Aslında İslam fikhı'nı yerli yerince anlayabilmek, söz konusu her iki kavramın ciddi olarak araştırılmasinı gerektirmektedir.

\section{Fıkıh ve Kavramsal Çerçevesi}

\section{A. Sözlükte Fıkıh}

F1kh, fakihe yefkahû'nün masdarıdır. Bilmek, anlamak ve kavramak demektir. Zarufe gibi fakuhe, yefkuhu, fekâhetün şeklinde de tasrif edilir. Efkahe açıklad1, fakkahe öğretti demektir. Herhangi bir şeyi bilen âlime fakîh, çoğuluna fukahâ denir. Konuşanın maksadını anlamada da "fıkh" sözcügü kullanılır. Fıkh, bilme anlamındaki ilimden daha özeldir. Sonra fikh, helal ve haram hususunda özel bir kullanım kazanıp bu bilgiye sahip olana fakih denilmiştir.

el-Isfahani (Ö.1108/502) fikh sözcüğünü, hazır bir bilgiyle bilinmeyene (gaib olana) ulaşma aracı olarak görmektedir. ${ }^{2}$

İbn Kayyim el-Cevziyye (ö.1350/751) fikh1, fehm'den daha özel bir anlamda görmektedir. Çünkü burada konuşanın maksadını kavrama sözlükteki mutlak anlamadan farklılık oluşturmaktadır. Kişilerin bu konudaki farklı algıları, onların ilim ve fikıh derecelerine etki etmektedir. ${ }^{3}$

1 Bkz. Abdulmecid eş-Şerefi, el-İslam Beyne'r-Risale ve 't-Tarih, 1.bs., Beyrut, Daru't-Talia, 2001, s. 140-143 ; İlhami Güler, Dine Yeni Yaklaşımlar, 3.bs., Ankara, Ankara Okulu Yayınları, 2016, s. 70-73.

2 Ebü'l-Kâsım Hüseyin b. Muhammed b. Mufaddal er-Rağıb el-İsfahani, Müfredâtü Elfazi'l-Kur'an, thk. Safvan Adnan Davûdi, 4.bs., Beyrut, ed-Daru'ş-Şâmiyye, 2009, s. 642.

3 Ebu Abdillah Şemsüddin Muhammed b. Ebî Bekr Eyyüp eş-Şehir bi-İbni'l-Kayyim el-Cevziyye, I'lamu'l-Muvakkiin An Rabbil âlemîn, thk. Abdurrauf Sad, Beyrut, Daru'l-Ceyl, 1973, 1/219. 


\section{B. Terim Olarak Fıkıh}

Fıkıh, bu anlamda farklı şekillerde tanımlanmaktadır. Bunlardan Hanefiler ile Şafii âlimlerinin tanımlarını birbiriyle karşılaştırarak izah edeceğiz.

Hanefilere göre fikıh, kişinin, lehinde ve aleyhinde olan şeyleri bilip tanımasıdır. Bilip tanıma(marife) dan maksat, tikel şeyleri delilleriyle öğrenmektir. Burada onların sebebi olan meleke söz konusu edilmektedir. Bu tanım, itikadî, amelî ve ahlakî konuları da kapsamaktadır. Nitekim Ebu Hanife'ye nispet edilen yukarıdaki tanımlama, o döneme uygundur. İtikat ile ilgili eserine el-F1khu'l-Ekber demesi de bundandır. Ancak daha sonraları Hanefiler, buna "amelen" kaydını ilave etmişlerdir. Böylece ameli hükümlerin dışındakiler, bu kapsamdan çıkmış oldu. ${ }^{4}$

Şafiiler fikhı şöyle tanımlamaktadırlar: Şer'i ameli hükümleri tafsili delillerinden elde ederek bilmektir. ${ }^{5}$ Buradaki "bilmek", hem kesin hem de ihtimalli şeyleri kapsamaktadır. Zira ameli hükümler, kesin delillerle sabit olduğu gibi ihtimalli/zanni delillerle de sabit olur. Fakihlerin, "fikıh zanniyat kapsamındadır" anlatımı, buna işaret etmektedir. Hükümlerin şer'i olmakla kayıtlanması, akli ve hissi olanları, ameli olmakla kayıtlanması ise itikadi ve ahlaki olanları, tanımın kapsamından çıkarmak amacına matuftur. ${ }^{6}$

Usûlcülere göre hüküm, hitabın kendisi, fakihlere göre de hitabın eseridir. Buna göre "zinaya yaklaşmayın" buyruğu usulcülere göre hüküm iken, fakihlere göre zinanın haramlığı bir hükümdür. Ancak bu ihtilafın pratikte bir sonucu yoktur. Hükmün teklifi ve vaz'i kısımlara ayrılması ve bu yöndeki detaylı izahlar ise konumuzun dışındadır.

"Tafsili deliller" kaydı, icmali delilleri tanımın dışında bırakmak içindir. Tafsili deliller muayyen ve tekil delillerdir. Namazın farziyetini ifade eden "akimu's-salate/namazı kılınız" ayeti gibi. Delil ise doğru bir araştırma ile arzulanan neticeye ulaştıran şeye denir. Bununla mukallidin bilgisi tanımın kapsamından çıkmış olur. ${ }^{8}$

4 Süleyman Muhammed b. Veli b. Resul Kırşehri İzmiri, Hâşiyetü'l-Fazli'l-İzmiri ale 'l-Mir'at, İstanbul, Matba-i Âmire, h.1309, 1/44.

5 Kadı'l-Kudât Tacüddin Abdulvehhab b.Ali b.Abdülkafi b. Ali b.Temmam b. Yusuf es-Sübkî, thk.Abdulmin'im Halil İbrahim, Cem 'u'l-Cevami'fi Usûli'l-Fıkh, 2.bs., Beyrut, Dâru'l-Kütübi'l-i̇lmiyye, 2002, s. 13.

6 Necmüddin Muhammed ed-Derkâni, et-Telkih Şerhu't-Tenkih li-Sadriş-Şeria, Beyrut, Dâru'l-Kütübi'l-İlmiyye, 2001, s. 9-10.

7 İsrâ, 17/32.

8 Abdulkerim Zeydan, el-Veciz fi Usûli'l-Fıkh, 1.bs., Beyrut, Müessestü'r-Risale en-Naşiru'n, 
Kimi fikhı, rey ve ictihat ile elde edilen bir ilim olarak tanımlamaktadır. $\mathrm{Bu}$ durumda, fikıh iyice düşünüp taşınma anlamıyla ön plana çıkmaktadır. Bunun içindir ki Allah Teala'ya fakih denilemez. Ancak bu tanımlama, fikhın sadece zanni konuları kapsamasına yöneliktir. ${ }^{9}$

el-Amidi (ö.631/1233) fikhın bu zanni boyutuna işaret etmek için "yorumlama ve delillendirme (nazar ve istidlal)yi, İbnu'l Hacib (ö.646/1249)" ise "dinin zorunlu olarak bilinen konularından olmamayı" fıkhın tanımına ilave etmiştir. ${ }^{10}$ Böylece açık nass ile sabit olan hükümlerle ictihadi olan hükümler ayrı tutulmuş olmaktadır.

Hanefilerin fikıh ile ilgili tanımları, fikhın zahiriyle beraber onun batıni/manevi yönünü de söz konusu etmektedir. Ancak terim anlamındaki fikhı ifadede Şafiilerin tanımı gibi açık ve mazbut görülmemektedir. Bundan dolaylıdır ki Şafiilerin tanımı, usûlcüler nezdinde meşhur olup tercih edilmiştir. ${ }^{11}$

\section{Kur'an'da Fıkıh ve Türevlerinin Kullanımı}

Kur'an'da 15 yerde fakihenin muzari kalıbı yefkahu ve türevleri, olumlu ya da olumsuz bir yapıda kullanılmıştır. Tevbe/122'de ise fakihe'nin (تفعل) tefa'aul kalıbından muzarisi çoğul olarak (يتفقهو ا) yetafakkahû şeklinde ifade edilmiştir. Bütün bunlarda yukarıda sözlük anlamlarında zikredilen özellikleri görmek mümkündür. ${ }^{12}$

Tevbe/122'deki “ليتفقهو ا فى الدين" anlatım1, mezkur ayetlerdeki kullanımlara göre bazı farklar taşımaktadır. Şöyle ki; tefa'aul kalıbının tekellüf (zorakilik) ve tedrice delalet etmesi, sözlük anlamına fazladan bir anlam katmaktadır. Ve yine dinde tefakkuh/derinleşmede bulunanların, bir taife/grup olarak zikredilmesi, ilmin kişisel boyutta kalmayıp toplumsal etkiye sahip olmasına önemli bir işareti barındırmaktadır.

2004, s.27; Şakir Beg el-Hanbelî, Usuûlu'l-Fıkh, 1.bs., Mekke, el-Mektebetü'l-Mekkiyye, 2002, s. 11-12.

9 Ali b. Muhammed b. Ali el-Cürrani, et-Ta'rifat, thk. İbrahim el-Ebyari, 1.bs., Beyrut, Dâru'l-Kitabi'l-Arabi, 1985, s. 216.

10 Ebü'l-Hasan Seyfeddin Ali b. Muhammed b. Salim Amidi, el-İhkam fi Usuli'l-Ahkam, ta. EşŞeyh İbrahim el-Acuz, 1.bs., Beyrut, Daru'l-Kütübi'l-İlmiyye, 1985, 1/8; Fahreddin Muhammed b. Ömer b. el-Hüseyin er-Razi, el-Mahsul fi-İlmi Usuli'l-Fıkh, 1.bs., Beyrut, Daru'l-Kütübi'l-İlmiyye, 1988, 1/10.

11 Bkz. ed-Derkani, a.g.e, s. 11.

12 Bkz. Nisa, 78; En'am, 25,65,98; A’raf, 175; Enfâl, 65; Tevbe, 128; Kehf, 93; Taha, 28; Hud, 91; İsra,146; Feth, 15; Haşr, 13; Münafikun, 3,7. 
Bazı önemli tabirlerine dikkat çektiğimiz ilgili ayet, mealen şöyledir: "Müminlerin toptan sefere çıkmaları doğru değildir. Onların her kesiminde bir grup, dinde tefakkuh (derinleşmek) ve kavimleri (savaştan) döndüklerinde onları uyarmak için geride kalmalıdır. Umulur ki sakınırlar."13

İbn Ebi Hatem, İkrime'den yukarıdaki ayetle ilgili olarak şöyle bir rivayette bulunmaktadır: "Şayet (cihad için) sefere çıkmazsanız, Allah size acıklı bir azapta bulunacaktır." ayeti indiğinde insanlardan bir kısmı, çöllerde bulunup kavimlerine dini bilgiler öğretiyorlardı. Münafiklar, çöldekiler helak oldu, diye yaygara kopardıklarında ilgili ayetler indi.

Abdullah b. Ubeyd b. Umeyr'den şöyle rivayet edilmiştir: Müminler, cihada olan aşırı arzularından dolayı, Peygamber bir seriyye gönderdiğinde hemen ona katılıyorlar ve böylece O’nu Medine'de az bir grupla başbaşa bırakıyorlardı. İşte ilgili ayet bu maksatla inmiş oldu. ${ }^{14}$

Demek ki dinde tefakkuh/derinleşme, cihad gibi farz-1 kifayedir. Müminlerden bir grup muhakkak onu yerine getirecektir. Peygamber hayatta olduğu müddetçe bir grup sürekli onunla beraber olmalıdır. Onlar hem vahye tanık olacaklar, hem de Hz. Peygamber'i münafikların kötü emellerine karşı savunacaklardır. Cihad gibi olağanüstü bir durumda dini öğrenme ve tebliğ etme, bu derece önemli olunca, bunun diğer zamanlarda asla ihmal edilmemesinin gerektiği, ilgili ayetten kendiliğinden anlaşılmış olur.

Kısacas1, müminlerden bir grup dinde bilgisini geliştirmek için, gerekirse yolculuk gibi zahmetlere katlanacak ve bunu bir cihad kabilinden sayacaktır. ${ }^{15}$ Ancak hangi durum olursa olsun, dinî ilimleri öğrenen ve öğreten bir grubun varlığı, her asırda önemli bir olgu olarak karşımıza çıkmaktadır. Zira Hz. Peygamber'in varlığına rağmen, buna ihtiyaç duyuluyorsa, buna diğer zamanlarda daha çok ihtiyaç duyulacağı açıktır.

\section{Sünnette Fıkıh ve Türevlerinin Kullanımı}

Kütüb-i Tis'a'da (dokuz hadis mecmuasında) fikıh, fakih, fukâhâ tabirleriyle, fikıh maddesinin mazi, muzari, emir ve ism-i tafdil kalıpları ile tefa'aul ve istif'a'l kalıplarının mazi ve muzarileri (tefakkahe, yetefakkahu, yestefkihu) kul-

13 Tevbe, 9/122.

14 Ebu'1 Hasen Ali b. Ahmed el-Vahidi en-Nisaburi, Esbabu'n-Nüzul, Beyrut, el-Mektebetü'l Asriyye, 2005, s. 139; Celaleddin Abdurrahman es-Suyuti, Lübabün-Nukûl fi Esbabin-Nüzul, thk., Muahmmed el-Fadili Beyrut, el mektebetü'l-Asriyye, 2006, s. 172-173.

15 Elmalılı Muhammed Hamdi Yazır, Hak Dini Kur'an Dili, İstanbul, Eser Yayınevi, t.y., 4/2647. 
lanılmıştır. Özellikle tefa'aul kalıbı, din ve Kur'an sözcükleriyle beraber ifade edilmiştir. ${ }^{16}$

İbnu'l-Esir (ö. 606/1210) fikh'ın yarmak ve açmaktan türetildiğine, örfi anlamda ise şeriat ve furuât ilimlerinde hususi olarak kullanıldığına dikkat çekmektedir. ${ }^{17}$

Sünnetteki tefa'aul (tefakkahe, yetefakkahu) kalıbının din ve Kur'an sözcükleriyle beraber kullanılması, Kur'an'daki kullanımında olduğu gibi yorum konusunda aceleci davranışlardan kaçınıp doğru neticelere ulaşmada olanca gayrette bulunmayı bizlere öğretmektedir. Çünkü dinî hitap, her şeyden önce sorumluluğu gerektiren bir özelliği kendinde barındırmaktadır.

\section{E. Fıkıh Sözcüğünün Tarihi Gelişimi}

Bu sözcüğü üç aşamada incelemek mümkündür. Şöyle ki;

Birinci aşamada fikıh, ilk asırdan, mezheplerin kuruluş dönemine değin itikadi, ameli ve ahlaki olmak üzere bütün dinî hükümlere uyarlanıyordu. F1kıh, şeriat ve din ile eş anlamlı görülüyor ve bununla, bizzat hükümler amaçlanıyordu. ${ }^{18}$ Nitekim Hz. Ömer'in de bir hutbesinde "F1kıh konusunda sorun sormak isteyen Muaz b. Cebel'e gelsin" sözüyle itikat ve amelle ilgili dini konuları kastettiği anlaşılmaktadır. ${ }^{19}$

Şunu unutmamak gerekir ki Hz. Peygamber döneminde fikıh, fakihlerin araştırmaları gibi bir meselenin rükun, şart ve adâbını tespit, tanımlama ve varsayımlar ortaya atma biçiminde değildi. Örneğin, Hz. Peygamber abdest alıyor, ashap da bunu görüp direkt uyguluyorlard1, namaz ve hac da bu minvâl üzere idi. ${ }^{20}$

İkinci aşama, ilimlerin ihtisaslaşıp birbirinden ayrıldığı dönemdir. Bu dönemde tafsili delilllerden elde edilen şer'i amelî hükümler, fikıh adıyla anılmaya başlamıştır. Burada hükümlerin doğrudan ya da dolaylı yolla ortaya çıkarılması arasında bir

16 A.J. Wensinck, Concordance Et İndices DE LA Tradition Musulmane, Leden E. J. Brell, 1955, 5/189-192.

17 Mecdüddin Ebu's-Seâdât el-Mübarek b. Muhammed el-Cezri İbnu'l-Esir, en-Nihâhye fi Ğaribi'l-Hadis ve'l-Eser, thk. eş-Şeyh Halil Ma'mun Şihâ, 4. bs., Beyrut, Daru'l-Ma'rife, 2011, 2/387.

18 Şa'ban Muhammed İsmail, Tarıhu'l-Teşrii'l-İslamî Mera'hiluhu ve Masadiruhu, 1. bs., el-Kahire, Daru's-Selam, 2010, s. 26-27.

19 Muhsin Koçak-Nihat Dalgın-Osman Şahin, İslam Hukuku, İslam Hukukuna Giriş, Aile Hukuku, Miras ve Ceza Hukuku, 3. bs., İstanbul, Ensar Neşriyat, 2016, s. 52.

20 Şah Veliyullah ed-Dihlevi, Hüccetüllahi'l-Baliğa, thk. Said Ahmed b. Yusuf el-Bâlenburi, 3. bs., Beyrut, Dâru İbn Kesir, 2017, 1/469. 
ayrım yoktur. Nihayet bu yeni terminoloji ile itikadi ve ahlaki hükümler, fikıh kapsamından çıkmış oluyordu. Aynı zamanda taklit ehlinin hükümlere ait bilgisi, araştırma ve delillendirmeye dayanmadığg için fikıh kapsamından sayılmamıştı.

Üçüncü aşamada, fakihlerin örfüne göre bütün dinî-amelî hükümler, -ister zorunlu dinî meselelerden olsun, ister ictihat ve taklit yollu elde edilsin- fikıh olarak adlandırılmaya başlandı. Böylece fakihlerin kendi imamlarının ictihatlarını yorumlama ve şerh faaliyetleri gittikçe yaygınlaşt. ${ }^{21}$

\section{F. Fıkhın İslam'a Nispeti ve Özellikleri}

F1kıh, -yukarıda ifade edildiği üzere- İslam'ın ameli yönlerini ihtiva eden disiplin olmakla bazı temel özellikler taşımaktadır. Bunlar, dayanılan kaynağın ayrıcalığına, tahakkuk ettirilecek gayenin yüceliğine ve diğer disiplinlerden farkındalığına bağlı olarak ortaya çıkmaktadır. Birçok detayı ve açıklamayı gerektiren bu özelliklerden en önemli olanlarına kısaca temas edeceğiz.

\section{Temelde İslami Vahye Dayanma ${ }^{22}$}

F1kıh, kitap ve sünnet kaynaklıdır. Bütün ictihadların bu iki kaynağın lafız ve ruhuna uygun olması gerekmektedir. Bu kaynağa dayanmayan yahut da ona aykırı bir biçimde ortaya atılan hiçbir görüş ve ictihad, dini sayılamaz.

Nitekim Yüce Allah bu meyanda şöyle buyurmaktadır: "Allah ve elçisi bir işe hüküm verdiği zaman, inanmış bir erkek ve kadına isteklerine göre seçme hakkı yoktur. Her kim Allah ve elçisine karş1 gelirse, apaçık bir sapıklığa düşmüş olur."²3

“Ey iman edenler! Allah'ın ve elçisinin önüne geçmeyin. Allah’tan korkun. Şüphesiz Allah işitendir, bilendir." ${ }^{24}$

\section{Hayatın Bütün Gereklerini Kapsama}

İslam fikhı, kişinin kendisi, Rabbi ve toplumu ile ilişkisini ifade etmektedir. Aynı zamanda, dünya ve ahiret mutluluğu temel gayedir. İslam fikhı, belli bir zaman ve mekanla sınırlanmadığı için hayatın bütün yönlerine hitap edebilme potansiyeli taşımaktadır. Diğer din ve beşeri ideolojilerde bu özelliği görmek mümkün gözükmemektedir.

21 Muhammed Mustafa eş-Şelebi, el-Medhal fi 't-Ta'rif bi'l-Fıkhi'l-İslami ve Kavaidu'l-Milkiyye ve'l-Ukûd fihi, Beyrut, Dâru'n-Nehda, 1985, s. 33; Abdulkerim Zeydan, el-Medhal li-Diraseti 'ş-ŞSeriati'l-İslamiyye, 1.bs., Beyrut, Müessesetü'r-Risale Naşirun, 2013, s. 61-63.

22 Başlıklar için bkz. Zeydan, el-Medhal, s. 65; Mehmet Erdoğan, İslam Hukukunda Ahkamın Değişmesi, 8. bs., İstanbul, İFAV Yayınları, 2014, s. 61-81.

23 Ahzab, 33/36.

24 Hucûrât, 49/1. 
Nitekim Yüce Allah şöyle buyurmaktadır: “...Bugün size dininizi ikmal ettim, üzerinize nimetimi tamamladım ve sizin için din olarak İslam'ı beğendim" 25

İslam fikhı, kişiyi anne karnında cenin halindeyken itibara alıp ölünceye kadar bütün dini ihtiyaçlarıyla değerlendirmekte ve ona göre hüküm altına almaktadır. Hatta o öldükten sonra vasiyet ve miras hukukunu hakkında icra etmektedir. ${ }^{26}$

İslam fikhı, insanoğlunun değişmez fitratı üzerine hükümler tesis eden değişmez ana kaynaklar ve bu kaynaklarda yer alan temel ilkelere sahiptir. Ayrıca bunların çerçevesinde oluşturulacak ictihada açık alan bırakması hasebiyle çeşitli şartlarda ve zamanlarda değişkenlik arzeden ihtiyaçlara cevap verecek nitelikleri barındırmaktadır. ${ }^{27}$

\section{Maslahatı Gözetme}

İslam fikhı, nassların tesisinde ve uygulanışında fert ve toplumun maslahatlarını makasid kapsamında görmektedir. Bunlar, bir yönüyle zaruri, hâci ve tahsini başka bir yönüyle de muteber, merdud ve mürsel olmak üzere kısımlara ayrılmaktadır. Muteber maslahat, bir hükmü ispat konusunda dinin itibara aldığı illet ve yarardır. Kumar ve içkinin yasaklanışı gibi. Merdud maslahat, dinî bir temele dayanmayan, hatta dinî açıdan iptal edilen bir maslahattır. Örneğin ekonomiyi güçlendirmek için kumar yerleri açmak gibi. Mürsel maslahat ise itibar ya da iptal edildiği bilinmeyen maslahattır. Müctehidler bunun hüccet olup olmaması konusunda ihtilaf etmişlerdir. ${ }^{28}$

Zaruri maslahat nefis, nesil, mal, ak1l ve dinin korunmasını hedefler. Kısas, tazminat ve hudut gibi hükümler bu cümledendir. Hâci maslahat, genişlik ve kolaylığı sağlamak için zorluk ve sıkıntının kaldırılmasını esas alır. Oruçta hastalık ve yolculara verilen ruhsat gibi. Tahsini maslahat adalet ve davranışlarda uygun ve güzel olanları uygulayıp kötü ve hoş olmayanları terketmekten ibarettir. $\mathrm{Bu}$ maslahat, aslında ilk iki maslahatın tamamlayıcısı konumundadır. ${ }^{29}$

25 Mâide, 53/.

26 Detay için bk. Muhsin Koçak (vd.leri), a.g.e., s. 61.

27 Muhsin Koçak, (vd.leri), a.g.e. s. 63; bkz. Dalgın, "Nihat, İslam Hukuku ve Evrenselliği", Mehir, 1999, sayı 3, s. 77-80; Türcan,Talip, İslamın Evrensel Hukuk Düşüncesine Katkıları, III. Kutlu Doğum Sempozyumu : Tebliğler, 2000, s. 25.

28 Ziyad Muhammed İhmidan, Makâsidu'ş-Şeriati'l-İslamiyye, 1.bs., Beyrut, Müessesetü'r-Risale, 2008. s. 263; Ebû İshak İbrâhim b. Musa b. Muhammed el-Gırnati Şatıbi, el-Muvafakiffi Usûliş-Şeria, thk. Abdullah Dıraz, 2. bs., Beyrut, Daru'l-Ma'rife, 1997, 1/324; Fahrettin Atar, Fıkıh Usülü, 6.bs., İstanbul, M.Ü. İFAV Yayınları, 2006, s. 79.

29 Ebû İshak İbrâhim b. Musa b. Muhammed el-Gırnati Şatıbi, a.g.e, cilt 1, s. 324. 
et- Tûfi (ö.716/1316), maslahatı nass ve icma'dan daha öncelikli görmektedir. Onun gerekçesi ise âlimlerden kiminin icma'ı inkar etmeleri ve dolayısıyla bunun itilaf konusu olması ve aynı zamanda nassların bazen farklı ve çelişkili anlamlar ihtiva etmesine dayanmaktadır. Ona göre maslahatta bu tür ihtilaflar bulunmamaktadır. ${ }^{30}$

et -Tûfi'nin maslahatla ilgili bu görüşleri bir çok âlim tarafından eleştiri konusu olmuştur. ${ }^{31}$ Burada detaya girmeden şunu ifade edebiliriz. Açık ve sabit nassa rağmen maslahatı esas almak, her şeyden önce nassın iptaline yol açabilecek uygulamaları intaç edecek riskleri taşımaktadır.

\section{Değişime Uygun Olma}

İslam fikhı, sabit olanların dişında zaman ve şartlar çerçevesinde oluşan olay ve sorunlarda ictihada dayanmakla, sürekli esneklik ve yenilenme özelliklerini kendinde taşır. Ancak bu yapıda görünme, onu dini olmaktan ayrı tutmaz. Nassların kapsamı dışında oluşan bir ictihat ise şer'i anlamda artık o adla anılma şerefinden mahrum kalır.

Aslında ictihadın bu noktada varlığı, İslam fikhının sürekliliğini de ifade etmektedir. Aksi halde zaman ve şartlara hitap etme kapasitesini kaybetmiş bir fikıh, İslami olmaktan uzak olmuş olur. Nitekim fikıh âlimleri "Zamanın değişmesiyle ahkamın değişeceği inkar olunamaz." "32 prensibini bu anlamda zikretmektedirler. Görülüyor ki İslam fikhı, insanların ihtiyaçlarını, örf ve adetlerini gayet önemsemektedir.

\section{Kolaylı̆̆ı Esas Alma}

Din yaşanmak için gönderildiğine göre bunun beşeri güç dahilinde olması gerektiği, gayet açık bir durumdur. Aksi halde sorumluluk, muhatabı aşan bir konumda gerçekleşmiş olur ki bu, açık ayetlere aykırıdır. Hükümlerin vahiy sürecinde duruma göre aşamalı olarak inmesi, azimet ve ruhsat özelliklerini taşıması, Mekke döneminde inanç ve ahlakın, Medine döneminde ise ahkamın beyan edilmesi durumları, bu hususun açık delilleridir.

30 Ebu'r-Rebi' Necmeddin Süleymanb. Abdülkavi b. Abdulkerim b. Said et- Tûfi, Risaletün fi Riayeti'l-Maslaha, thk. Ahmed Abdurrahim es- Sayih, 1. bs., y.y., ed-Daru'l-Misriyye el-Lübnaniyye, 1993, s. 34.

31 Muhammed Said Ramazan el- Bûti, Davabitü'l-Maslaha fi'ş-Şeriati'l-İslamiyye, 4. bs., D1maşk, Daru'l-Fikir, 2005, s. 216-220.

32 Bkz. Abdulkerim Zeydan, el-Vecîz fi Şerhi'l-Kavaidi'l-Fıkhiyye fi'ş-Şeriati'l-İslamiyye, 2. bs., Beyrut, Müsessesetü'r-Risale, 2014, s. 104. 
Nitekim Yüce Allah bu konuda şöyle buyurmaktadır: "O, sizi seçti. Din hususunda üzerinize hiçbir zorluk yüklemedi." ${ }^{33}$

"Allah sizin için kolaylık ister, zorluk istemez." 34 "Allah size herhangi bir güçlük çıkarmak istemez, fakat sizi tertemiz k1lmak ve size (ihsan ettiği) nimetini tamamlamak ister. Umulur ki şükredersiniz." ${ }^{35}$

Fakihler, söz konusu ayetlerden hareketle, "Meşakkat, kolaylığ celbeder."36 prensibini ortaya koymuşlardır. Tabi ki bundan fikhi hükümlerin hiç meşakkat ihtiva etmemesi anlaşılmasın. Teklifin kendisi az da olsa meşakkati yapısında barındırmaktadır. ${ }^{37}$

\section{Zarûreti Gözetme}

İslam fikhı, iman-küfür, helal ve haram çizgisini esas almakla beraber, zarûret durumlarında bu sınırları korumayı geçici olarak askıya alabilmektedir. Zira insan hayat1, böyle bir durumda her şeyden daha önemli bir konumda olup onun korunması önceliklidir.

Nitekim ikrah (zorlama) halinde kalp meyletmemek şartıyla, küfür kelimesini söyleme izni, aşırı açlık ve susuzluk gibi durumlarda haram olan yiyecek ve içeceklerin zaruret miktarı kullanabilmesi gibi durumlar, açık ayetlerle sabittir. ${ }^{38}$

Zaruret birbirine yakın anlamlarla tanımlanmaktadır. Burada temel espri, haram olan bir şeyi işlemeye zorlayıcı bir durumun ortaya çıkmasıdır. Yani, kişi onu yapmadığında ölüm tehlikesi ile karşı karşıya kalmalıdır.

Nitekim fakihler "Zaruretler mahzurlu şeyleri mübah kılar." prensibini yukarıda zikredilen ayetlere dayandırarak ortaya koymuşlardır. Şunu da unutmamak gerekir. Zaruretlerin bu konumu, geçici ve istisnâidir. Zaruret durumu kalkınca hüküm asıl şekline döner. Bazı zaruretler örneğin, başkasını öldürmekle yahut zina yapmakla zorlanan biri, bu fiilleri işleyemez. ${ }^{39}$

33 Hac, 22/78.

34 Bakara, 2/185.

35 Mâide, 56/.

36 Zeydan, el-Veciz fi Şerhi'l-Kavaid, s. 53.

37 İbn Faris, a.g.e s. 875; Ahmet Yaman- Halit Çalış, İslam Hukukuna Giriş, 10.bs., İstanbul, M.Ü. İFAV Yayınları, 2015, s. 203. Ayrıca Bkz. Rifat Uslu, "İslam Hukukunda Kolaylık Prensibi”, Uluslar Arası Sosyal Araştırmalar Dergisi ( The Journol Of International Social Research), cilt VIII, say1 36, 2015, s. 479-494.

38 Nahl, 16/106; Bakara, 2/173; Mâide, 5/3.

39 Bkz. Zeydan, el-Vecîz fi Şerhi'l-Kavâid, s. 67-70. 


\section{II. Şeriat ve Kavramsal Çerçevesi}

\section{A. Sözlükte Şeriat}

Şeri’a, su kaynağı anlamındadır. Bunda açığa çıkma, açığa çıkarma yönü ağır basmaktadır. Şeraâ, yeşra'u, şer'an ve şurûan kökünden türetilmiştir. Araplar su durup kesilmedikçe ona "şeriat" derler. Şir'a ise geniş yol ve bir şeyin benzeri olma anlamındadır. Büyük yola da şâri' denir. ${ }^{40}$

el-Isfahaniye göre "şeriat" sözcüğü iki şeye delalet etmektedir.Bunlardan biri, Allah'ın, herkesin fitratına yerleştirdiği ve onun, hayatı boyunca araştırıp geliştireceği yetenek; diğeri ise kişinin, kendi istek ve iradesiyle tercih ettiği ve nesh yoluyla değişen farklı şeriattır. Nesh kabul etmeyen dinin asılları da şeriatın bu ikinci anlamı kapsamındadır. ${ }^{41}$

\section{B. Terim Olarak Şeriat}

Şeriat, Allah Teala'nın kulları için koymuş olduğu dinî, dünyevi hükümlerin bütünüdür. Hem itikadi, hem ameli hem de ahlaki hükümleri içerir ve buna göre şeriat, din kelimesiyle eş anlamlıdır.

Bazen şeriat, nasslarla belirlenmiş sadece ameli fer'i hükümler hakkında kullan1lır. ${ }^{42}$

Nasslarla belirlenmiş hükümlerden amaç, kitap ve sahih sünnet ile sabit olan hususlardan ibarettir. ${ }^{43}$

Kimi araştırmacılar, Allah'ın yolu dışında kalan beşeri sistem ve kanunlara şeriat denilemeyeceğini belirtmektedir. ${ }^{44}$ Ancak sözlük açısından buna bir engel yoktur. Nitekim örfi anlamda beşeri kanunlar da şeriat/teşri adıyla anılmaktadır. ${ }^{45}$ Yüce Allah, müşiklerin fillerini teşri ve inançlarını din olarak nitelemektedir: "Yoksa onların, Allah'ın izin vermediği bir dini teşri eden ortakları mı var?"

40 İmam Halil, a.g.e., s. 473-474; İbn Faris, a.g.e., s. 533; İbnu'l-Esir, a.g.e., 2/857.

41 el-Isfahanî, Müfredât, s. 450.

42 Mehmet Erdoğan, Fıkıh ve Hukuk Terimleri Sözlüğü, 5. bs., İstanbul, Ensar Neşriyat, 2015, s. 524.

43 Zeydan, el-Medhal, s. 38.

44 Menna el-Kattan, Tarihu 't-Teşrii'l-İslamî, 2.bs., Beyrut, Müessesetü'r-Risale, 1982, s. 15-16.

45 Ferit Devellioğlu, Osmanlıca Türkçe Ansiklopedik Lügat, 25. bs., Ankara, Aydın Kitabevi, 2008, s. 1097.

46 Şûra, 4221/. 


\section{Kur'an'da Şeriat ve Türevlerinin Kullanımı}

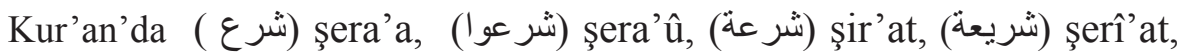
(شرعا) Şurr'âan kullanımları geçmektedir. ${ }^{47}$ Demek ki mazi fiilinin tekil ve çoğul kalıbı ile masdar ve isim söz konusu edilmiştir.

A'raf, 7/163'teki (شر عا) şurra'an, açığa çıkma, akın akın gelme şeklinde sözlük anlamında kullanılırken, diğer ayetlerde din ile beraber ve o kapsamda yani, din kurma şeriat sahibi kılma ve belirli bir şeriat üzere olma anlamlarında kullanılmıştır.

Elbette ki şera'a fiilinin Yüce Allah'a nispeti, Hz. Peygamber'in şeraa'nın türevlerinden biriyle muhatap kılınması yahut bunun din ile kayıtlanması, sözü edilen terimsel şeriati açıkça ifade etmektedir. Terimsel anlamdaki şeriatın farklı bakış açılarıyla yorumlanması, meselenin özüne olumsuz etkide bulunacak türden bir ihtilaf sayılmaz. Burada sözlük anlamıyla terimsel anlam arasında sıkı bir ilişki bulunmaktadır. Bu husus ise İslam şeriatının su kaynağındaki temizlik, berraklık ve devamlılık yönlerini kendinde bulundurmasıyla izah edilebilir.

Kuran'da şeriat ve türevlerinin kullanımı, genel olarak bireysel ve toplumsal hayatı düzenleyici kurallar anlamını ihtiva etmektedir. İslami değerler bütününü ifade eden ve aynı zamanda İslami düşünüşün temel bir unsuru olan şeriat ve şer kavramını, klasik kaynaklarda tarihsel süreçte din kavramından daha çok vurgulanmıştır. Ancak bunların literatürde yaygınlaşması II. (VIII.) yüzyıldan sonra olmuştur. ${ }^{48}$

\section{Sünnette Şeriat ve Türevlerinin Kullanımı}

Kütüb-i Tis'a'da şeraa, şârian, eşraa, şer'un şeriatûn (çoğulu şerâi) ve meşra'a tabirleri geçmektedir. Şeraa bazen din, şeriat ve şerâi ise İslam sözcüğüyle kullanılmıştır. Bazen şerâi, farzlara karşılık gelecek şekilde kullanılmıştır. ${ }^{49}$ Bu durumda şeriat kavramı, ameli hükümleri ifade etmiş olur. "Şer'" ve "şeriat" sözcükleri, hadislerde farklı yerlerde tekrarlanmıştır. Teşri' ${ }^{50}$, deve sahiplerinin, develerini kuyuya götürme ihtiyacı duymadan, onları direkt su kaynağına götürmelerini ifade etmektedir.. Yahut develerin önceden oraya bırakılıp sonra

47 Şûra, 4213,21/; Maide, 48; Casiye, 18; A’raf, 7163/

48 Talip Türcan, "Şeriat", İslam Ansiklopedisi, cilt XXXVIII, İstanbul, TDV İslam Ansiklopedisi Genel Müdürlüğü Yayını, 2010, s. 571-574. Ayrıca daha geniş bilgi için bkz. Ayhan Ak, İslam Hukuk Felsefesi, İstanbul, Ensar Neşriyat, 1. bs. 2014, s. 52-63.

49 Concordance, 3/100-101.

50 Müslim, Mesacid, 357; Ebu Davud, Salat 46; Nesai, İmame; 50. 
su ihtiyaçlarının giderilmesidir. Eşraa fi'l-adudi, ${ }^{51}$ suyu pazusuna ulaştırma yani, pazuyu, yıkamaya dahil etme demektir. Şâria, ${ }^{52}$ kapıların mescide açık olması anlamında kullanılmıştır. Şirau'l-enf, uzun burunlu, Şira', yelken, şer'; eşit olma ve yeterli olma anlamlarındadır. ${ }^{53}$

\section{E. Şeriatın Özellikleri}

Şeriattan maksat, İslam şeriatıdır. Zira şeriat kavramının kanun anlamında kullanılması mümkün olduğu için, burada böyle bir kayıtlamaya ihtiyaç duyulmaktadır. İslam fikhının özellikleri ile İslam şeriatının özellikleri temelde aynı olduğu için, bu konuda aynı şeyleri tekrar etmeyeceğiz. Ancak şurası var ki İslam fikhının/hukukub,nun kaynağı anlamındaki ${ }^{54}$ İslam şeriatı, sabit, açık ve yorumdan uzak olma özellikleriyle fikha kaynaklık yapacak bir konumda bulunmaktadır. Belki de bu özellikler, fıkhi ihtilafları disiplinize edecek bir yapıyı gözler önüne sermektedir.

İslam şeriatında hükümler, adalet, eşitlik, şûra gibi genel prensipler ile inanç, ibadet, ahlak ve fert ilişkileri gibi detaylı meseleler olmak üzere iki kısmı ihtiva etmektedir. Her iki kısım da zaman ve mekana uygun bir şekilde şeriatın devamlılığını ve kapsamlılı̆ğnı ihtiva etmektedir. ${ }^{55}$

\section{F. İlâhi Şeriatler Arası İlişki}

Yüce Allah, bir çok şeriatler göndermiştir. Zira hiçbir ümmet uyarıcısız b1rakılmamıştır. Ahirette azabın gerçekleşmesi, uyarıcı elçinin gönderilmesine bağlanmıştır. ${ }^{56}$ Buna göre bütün ilahi şeriatler, kaynaklık, inanç ve genel hedefler açısından eşit konumdadır. Ancak ameli ve cüz'i konularda şeriatler farklıdır. Nesh olayı bundan ötürü sözü edilen durumlarda gerçekleşir.

İslam şeriatı, önceki şeriatlerden bazı hükümleri neshetse de bütünüyle Allah'ın, elçisine indirdiği vahye dayanmaktadır. Kur'an ve sünnetin inkar ve ikrar etmeksizin kendilerine işaret ettikleri önceki şeriatlerin bizim için kabul edilip edilmeyeceği tartışılmakla beraber, cumhura göre bunlara uyulması gerekmez. Bazıları da bu anlamda önceki şeriatın da geçerli olması gerektiğini söylemekte-

51 Müslim, Tahare, 34.

52 Ebu Davud, Tahare, 92.

53 İbnu'l-Esir, a.g.e., 1/857.

54 Abdulkerim Zeydan, el-Medhal li-Diraseti'ş-Şeriati'l-İslamiyye, s. 39; Ekrem Buğra Ekinci, Íslam Hukuku, 1. bs., İstanbul, Ar1 Sanat Yayınları, 2006, s. 26.

55 Abdulkerim Zeydan, el-Medhal li-Diraseti'ş-Şeriati'l-İslamiyye, s. 48.

56 Yunus, 10/47; Kasas, 28/59; Fâtır, 35/24. 
dir. ${ }^{57}$ Ancak Zeydan'ın da vurguladığı gibi Kur'an ayetleri, her ümmet için ayrı bir şeriat ve yol konduğunu ve bizim Hz. Peygamberimiz'e şeriat olarak indirilene uymamız gerektiğini açıklamaktadır. ${ }^{58}$

\section{Fıkıh ve Şeriat İlişkisi}

F1kıh ve şeriat kavramları sözlük anlamlarıyla farklı olsalar da terim olarak birbirleriyle sağlam bir ilişki içerisindedirler. Fıkhın geçirdiği tarihi süreç de buna tanık olmaktadır. Fıkıh sözcüğü, -yukarıda geçtiği üzere-Kur'an ve sünnet nasslarında mevcut olup sonradan uydurulmamıştır.

Her iki kavramın mezkur ilişkisi müsellem olduğuna göre bunların birleştikleri ve ayrıldıkları yönlere temas etmemiz uygun olacaktır.

\section{A. Genellik-Özellik}

Yukarıdaki açıklamalarımızdan anlaşıldığı üzere geniş anlamıyla şeriat, İslam dininin inanç, ibadet, muamelât, hudûd ve ahlak olmak üzere bütün hükümlerini kapsamaktadır. Buna karşılık, fikıh sadece hükümlerin ameli yönlerini konu edinmektedir. Dolayısıyla, şeriat genel, fıkıh özel olmaktadır. Fıkıh ve şeriat, ameli hükümlerde kesişirken, diğer hükümlerde birbirinden ayrılmaktadırlar. Bu noktada ameli hükümleri, hem şeriat, hem de fikıh adıyla anmak, ittifak konusu olmuş olur..$^{59}$

\section{B. Kaynaklık}

Şeriat, Allah'ın, Peygamberine beyan edilip uygulanması için gönderdiği dindir. Beşeri düşünce ve algıların bunda bir etkisi yoktur. Kur'an ve sahih sünnet asıl kaynaktır. Bu durum bütün müslümanları bağlayıcıdır. Dolayısıyla buna aykırılık caiz değildir.

Fıkıh ise asli kaynakta şeriâtle birleşse de bunların dışında icma, kıyas vb. kaynaklara da dayanmaktadır. Ancak bu kaynaklar, Kur'an ve sünnetin, meşrulaştırılmasıyla geçerli olabilmektedir. Şayet şeriat, fikhın dayandığı söz konusu kaynakları reddetseydi, fakih, bunlardan şer'i bir hüküm çıkarma yetkisine sahip olamazd $1 .{ }^{60}$

57 el-Mahallavî, Muhammed Abdurrahman Îyd, Teshîlu'l- Vusûl ila İlmi'l- Usûl, Misır, Matbaatu Mustafa el- Baba el-Halebî ve Evladuhu, 1341, s. 166.

58 Abdulkerim Zeydan, el-Medhal li-Diraseti'ş-Şeriati'l-İslamiyye, s. 68-70.

59 Şeriat-fikıh lişkisi hakkında bkz. Abdulkerim Zeydan, el-Medhal li-Diraseti'ş-Şeriati'l-İslamiyye, s. 63.

60 Abdulkerim Zeydan, el-Medhal li-Diraseti'ş-Şeriati'l-İslamiyye, s. 63-64. 
Görülüyor ki şeriat ile fikıh, Kur'an ve sünnet'te birleşmektedir. Ancak fikıh, diğer kaynaklar konusunda zahiren şeriatten ayrı görünse de onun onayı dahilinde hareket etmek şartıyla dolaylı olarak kendisiyle birleşmiş olmaktadır. İşte bu noktada fakihlerin ortaya attıkları görüş ve ictihadların farklılığı, meşru bir zemine oturtulmuş olmaktadır.

\section{C. İlahilik-Beşerilik}

Şeirat, doğrudan doğruya nasslara ve onların açık anlamlarına dayanmakla, onda asla ihtilaf varit olmaz. ${ }^{61}$ Şeriatı tesis eden Yüce Allah'tır. Hz. Peygamber, O’nun izni kapsamında beyanda bulunur. Onun yerine beşeri anlamda bir şeriat tesis etmek, Yaradan'ın vasıflarını geçersiz saymak, yahut kendini, O'nun yerine koymak anlamı taşır.

Fıkıh, şeriatın nasslarına dayansa da onun hükme medar olan bazı delillendirme şekilleri, tartışma konusu olmuştur. Ayrıca fakih, beşer olması yönüyle hakkında açık nass bulunmayan hususlarda yanılabilir. Zaman ve şartların değişmesiyle gelişen olaylar ve onların algılanış biçimleri, hüküm istinbatına etki edebilmektedir. İşte bu noktada beşerilik söz konusudur. Şu var ki buradaki beşerilik, mutlak olmayıp Kitap ve Sünnet ile kayıtlıdır. Onun için fikhın müctehitlere nispet edilmesi örneğin, Ebu Hanife'nin fikhı, Şafii'nin fikhı vb. tabirlerinin kullanılması caizdir. Görülüyor ki terimsel anlamda fikıh, bu yönüyle şeriatten ayrıdır. Ancak fikıh, bütünsellik yönüyle İslam şeriatinin prensip ve esaslarına dayanmakla, onun sistemi içerisinde mütalaa edilmelidir.

Fakihlerin aynı meselede farkl1, hatta birbirine zit ictihatlarda bulunmaları, bu yönle ilgilidir. Şurası önemle belirtilmelidir ki söz konusu farklılık, açık ve kesin anlamlı nasslarda olmayıp rivayet ya da delâlet yönü ihtimalli ve aynı zamanda hakkında hiç nass bulunmayan nevzuhur meselelerde olur. Böyle bir durumda bağnazlığa düşmeden sağlam deliller muvacehesinde davranmak, mutedil ve ilmi olan bir tutumdur. ${ }^{62}$

İctihatta doğruya ulaşma ya da hata etme konusunda âlimler farkl1 görüşler ortaya atmışlardır. Konuyla ilgili olarak Ebu Hanife ve Şafii'den değişik rivayetler aktarılmıştır. Özetle kimi, her müctehidin zanni konularda doğruyu bulduğunu, kimi de doğruyu bulanın, tek olduğunu belirtmiştir. Birinci grup musavvibe, ikincisi ise muhattie olarak adlandır1lır.

Her iki grup da hakkında nass olmayan olayın Allah katında belirli bir hükmünün olup olmamasında ihtilaf etmişlerdir. Musavvibenin muhakkiklerine göre

61 Abdulkerim Zeydan, el-Medhal li-Diraseti'ş-Şeriati'l-İslamiyye, s. 39.

62 Bkz. Abdulkerim Zeydan, el-Medhal li-Diraseti'ş-Şeriati'l-İslamiyye, s. 64. 
burada hüküm, müctehidin zannına tabidir. Kadı Bakıllani (ö. 403/1013), Müzeni (ö. 264/878) ve Gazzali'nin (ö. 505/1111) tercih ettikleri görüş budur. Musavvibeden bir gruba göre ise burada belirli bir hüküm bulunmaktadır. Dolayısıyla bunun araştırılması gerekmektedir.Ancak müctehid doğruya ulaşmamakla sorumlu tutulamaz. Bundan böyle hata etse de neticede doğruyu bulmuş olur.

Muhattieye gelince; onlar bu konuda Allah'1n belirli bir hükmü olduğunda ittifak etmişlerdir. Ancak bu konuda delilin olup olmamasında ihtilaf etmektedirler. Bir kısmına göre hükümde delil yoktur. Bir kısmına göre ise hüküm, bir define gibidir, arayan büyük çaba ile onu bulur. Artık doğruya ulaşan iki ecir, ulaşamayan ise çabasından dolayı bir ecir alır. Fukaha ve kelamcılardan bir grubun görüşü, bu minvâldedir. Bu görüş Şafiilere nispet edilmektedir. ${ }^{63}$

Hükümde delil olduğunu söyleyenler de bunun kat'i ve zanni oluşunda ihtilaf etmektedirler. Kat'i olduğunu söyleyenler müctehidin delili kesin elde edip doğruya ulaştığ 1 yönünde ayrılığa düşmüşlerdir. Kimine göre bu durumda müctehid mazur olup sevap alır. Kimine göre de hata ettiğinde sevap elde etmez, ancak günah da işlemiş sayılmaz. ${ }^{64}$

Yukarıda aktarılanlar 1şığında denilebilir ki aslında hüküm, zanni olduğu için hata ihtimali her zaman mümkündür. Kitap ve sünnet bu haliyle ictihada izin verdiğine göre doğruya ulaşıp ulaşmama, aynı konumda olmuş olur. ${ }^{65}$ Hükmün Allah katındaki durumu bilinmediğine göre bunu tartışmanın bir anlamı yoktur. Burada önemli olan müctehidin ehil olması ve hükmü delil açısından olanca çabasıyla araştırmasıdır. Ancak bu meyanda nassa açık bir şekilde aykırı olduğu anlaşılan bir ictihad, bu kapsamda görülmemelidir. Zira nassın varit olduğu yerde ictihada açık alan yoktur. ${ }^{66}$

Fıkıh ve şeriatın yukarıda anlatılan ayırımı, fikhın, rey ve ictihat ile elde edilen bir ilim olarak tanımlanmasına uygundur. Zira bu tanımlama, sadece zanni konuları ihtiva etmektedir. Ancak fikhın diğer tanımları mülahaza edildiğinde fikıh ve şeriat, iç içe olup sadece ameli hükümlerde birbirinden ayrılmaktadır.

63 Fahreddin Muhammed b. Ömer b. el-Hüseyin er-Razi, el-Mahsul fi-İlmi Usuli'l-Fıkh, 1. bs. Beyrut, Dârü'l-Kütübi'l-İlmiyye, 1988, 2/503-504.

64 el-Gazzali, Ebu Hamid b. Muhammed, el-Mustasfâ min İlmi 'l-Usûl, thc. Tâha eş-Şeyh, Kahire, el-Mektebetü't-Tevfikiyye, 2010, s. 651; bkz. İzmirli İsmail Hakk1, İlmi-i Hilaf, Sad, Fuat Ateş, Konya, Hüner Yayınevi, 2010, 1/268-269.

65 Bkz. Tevbe, 9/122; Nisa, 4/59; Buhari, İ'tisâm, 21; Müslim, Akdiyye, 15; Ebu Davud, Akdiyye, 2; Tirmizi, Ahkâm, 2.

66 Bkz. Tevhid Ayengin, "Hukuki Dinamizm ve İctihadda İsabet Tartışmaları", Ma'rife, sayı 8, K1ş, 2012, s. 139-158. 
Allal el-Fasi'nin (1910-1974) dediği gibi din Allah'ın koyduğu hükümler, şeriat, sünnet ve hüda, fikıh ise bunların bütünüdür. Şeirat yol, fikıh ise onun yorumu ve açıklamasıdır. Buradan bir sonuca ulaşacaksak o da fikhın, şeriatten ayrı olmayacağı ve onun dişında gerçekleşmeyeceğidir. ${ }^{67}$

\section{IV. İslam Fıkhının Beşeriliğinin Argümanları}

İslam fikhının şeriat kapsamında olduğu ve bu yönüyle ilahi temele dayalı bir yapı ve özellik taşıdığ yukarıda anlatıldı. Ancak ictihad ameliyesi çerçevesinde zaman ve şartlara göre değişen yapısı, kimine göre onun tamamen beşeri bir sistem şeklinde algılamasına neden olmuştur. Biz, bu algı sahiplerinin bu meyanda ileri sürdükleri bazı argümanları değerlendireceğiz.

\section{A. Kaynaklık Sorunu}

Kimine göre kitap-sünnet ile sabit olan fikhi ve hukuki hükümler, salt ilahi, değişmez, ebedi olarak "din” şeklinde algılanmamalıdır. Zira sünnet, Hz. Peygamberin Kur'an'dan anladığı şahsi ictihatlarını temsil etmektedir. Bunlar, olaylarla paralel olarak canlı ve dinamik bir biçimde oluşmuştur. Kitap-sünnet bu konumda olunca icma ve kıyasın konumu daha da sorunlu gözükmektedir. Zira icma ve kıyas bu anlayışa göre zaten beşeri bir kaynaktır. Neticede, Kur'an ve sünnet ile sabit olan hükümler, bizzat dinin özünden değil, onun dolaylı, işlevsel bir aracı olmakta ve hukuki bir yasada dinin temel maksadı dikkate alınmaktadir.

Modern ve tarihselci yaklaşımı temsil eden bu görüş sahipleri, din ile hukuku birbirinden ayırmakta, maslahatı gerçekleştiren her türlü hukuki düzenlemeleri, dine aykırı saymamaktadır. Onlara göre İslam tarihinde hukukun dinden sayılması ve kıyas yoluyla dini nasslara bağlanması, onun gerilemesine ve donmasına sebep olmuştur. ${ }^{68}$

Yukarıdaki iddia, Müslümanların kaynak olarak üzerinde ittifak ettikleri sünneti, devre dışı bırakma ve böylece Kur'an'ı tek kaynak olarak gösterme çabasını taşımaktadır. Sünnetin hücciyeti, birçok kez izah ve ispat edildiğ ${ }^{69}{ }^{6}$ için bu konuda sözü uzatmadan bazı noktalara dikkat çekeceğiz.

67 Allâl el-Fâsi, Müfekkiretü'l-Fıkhi'l-İslami ve Mukârenetühü bi'l-Fıkhi'l-Ecnebi, er-Ribat, Müessesetü Allâl Fâsi, t.y., s. 15.

68 Örnek olarak Bkz. İlhami Güler, a.g.e., s. 70-73.

69 Bkz. Muhammed Muhammed Ebu Zehv, el- Hadis ve'l-Muhhaddisûn, Beyrut, Daru'l- Kitabi'l-Arab'î, 1983, s. 21; Alya Şeyh Muhammed, Silatu's-Sünneti bi'l-Kur'an ve Reddu Şubuhat Muasıra, 1. bs., Dımaşk, Daru'l-Feyha, 2000, s. 69-91. 
Kur'an, vahyin temel kaynağıdır. Hz. Peygamber tebliğ görevini yerine getirirken, onu beyan etme yetkisine sahiptir. ${ }^{70}$ Malumdur ki Kur'an'ın kendisi, bizzat insanlarla diyalogta bulunup uygulanmaz. Şimdi, 22 küsûr yılda inen vahiy sürecinde Hz. Peygamberin ya hiç konuşmadığı yahut konuştuğu halde onun bu beyanının bir değerinin olmadığı iddia edilebilir mi? Her iki iddia da yanlış olduğuna göre neticede Hz. Peygamber'in aldığı vahyi insanlara onların anlayacakları dille açıkladığı kaziyesi ortaya çıkar. Zaten Kur'an'ın kendisi buna işaret etmektedir. ${ }^{71}$ Demek ki Kur'an'ın dışında onu açıklayan ve uygulanışına vesile olan kaynağın -ki oda sünnettir- bulunması gerekmektedir. Aksi halde Kur'an'ın anlaşılması ve uygulanışı, akıl ve realite açısından mümkün değildir.

Sünnetin rivayet şekline gelince; bu durum Hadis Usûlü kitaplarında detaylı olarak anlatılmıştır. Ancak şunu ifade edelim ki İslam ümmeti, bütünüyle Peygamber'ine iftira edip hadis uyduracak değildir. Ümmetin hayırlı kılınışı ve diğer ümmetlere şahit oluşu ${ }^{72}$ buna yol vermez. Üstelik hadis olgusu, haber ve rivayet metotları çerçevesinde araştırılmış sıhhat şartlarını taşıması durumunda kabul edilmiştir. Hadislerin uzun ve yorucu araştırmalar neticesinde tashih edilmesi, derece ve kısımlara ayrılması, isnattaki ricalin ciddi araştırmalara tabi tutulması, özellikle zayıf ve uydurma rivayetlerin ayıklanması ve bütün bunlarla beraber, hadisi tashihte hata yapılabileceğinin itirafi, ahad rivayetlerin sadece zanni meselelerde delil olabileceği vb. durumlar, ${ }^{73}$ üzerinde durulması gereken önemli hususlardır.

İcma ve kıyas konusuna gelince; icma, herhangi bir asırda yaşayan müctehitlerin tamamının bir fıkıh hükmü üzerinde ittifak etmeleridir. İcma, kitap ve sünnetten şer'i bir kaynağa dayanmak zorundadır. Aksi halde heva ve arzuya uyulmuş olur. Kitaptan örnek şöyledir: "Size anneleriniz ve kızlarınız haram k1lınd1." 74 ayetinde nineler ve torunlar zikredilememektedir. Bu anlamda usûl ve furuun -derecesi ne olursa olsun- haramlığ icma ile sabit olmuştur. ${ }^{75}$

Sünnetten ise ashabın nineye altıda bir verileceği üzerine icma etmelerini ${ }^{76}$ örnek gösterebiliriz. İcmaın ictihad ve kıyasa itimat edip etmeyeceği ise tartış-

70 Nahl, 16/44.

71 İbrahim, 14/4.

72 Âl-i İmrân, 3/110.

73 Bkz. Osman b. Abdirrahman b. Osman İbnu's-Salah el-meşhur bi İbn.Salah eş-Şehrezûrî, Mukaddimetü İbn Salah fi İlmi'l-Hadis, ta. Üsame el-Belhi, Beyrut, Daru'l-Kitabi'l-Arabi, 2005, s. $13,27,233$.

74 Nisâ, $4 / 23$.

75 Ebu Abdillah Muhammed b. Ahmed el- Ensari el- Kurtubi, el Cami' li-Ahkami'l-Kur'an, 1. bs., Beyrut, Daru'l-Kütübi'l-İlmiyye, 1988, 5/70.

76 Abdülkerim Zeydan, el-Veciz fi Usûli'l-Fıkh, s. 178. 
malıdır. İbn Davud ez-Zahiri (ö. 297/910), İbn Cerir (ö. 310/923) gibi alimler bunu kabul etmemekle birlikte, çoğu âlimlere göre bu caizdir. İcmain bağlay1c1 bir delil oluşu, "müminlerin yolundan ayrılmayı kınayan ayet ${ }^{77}$ ile ümmetin sapıklık üzere birleşmeyeceğini ifade eden hadis rivayetlerine ${ }^{78}$ dayanmaktadır." ${ }^{\prime 79}$ Demek ki icma, ister kitap-sünnete, ister ictihat ve kıyasa dayanmış olsun, her iki durumda da fikhi bir meseleyi ihtilaftan kurtarıp ittifaka vesile olan bir delil şeklidir. Bunun Hz. Peygamber döneminde olup olmaması, bu anlamda sorun oluşturmaz. Zira neticede ya nassa ya da ictihada uyulmuş olunmaktadır. İctihadı, ferdi ve ictimai (toplumsal) olarak telakki ettiğimizde, icma, ictimai kısımdan sayılabilir. Nasıl ki ferdi anlamda ictihad caiz ise ictimai, anlamda da onun cevazı, evlâ olur.

Kıyas ise hakkında nass olmayan bir meseleyi, nass ile sabit olan bir meseleye, aralarındaki ortak illet sebebiyle katmaktadır. ${ }^{80}$ İlleti tespit etmenin birçok yolu bulunmaktadır. Müctehit bu konuda bütün gayretini sarfedip bir neticeye varmakla sorumludur. Aslında bu durum, dini nassların bir sebep ve maksada dayandığını ve böylece kulların maslahatını gözettiğini göstermektedir. ${ }^{81}$ Ayrıca İslam'ın her çağa uygulanabilirliği, bu ictihat kıyasıyla orataya çıkmaktadır.

Zahirilerle, bazı Mu'tezile ve Caferiler, kıyası kabul etmeseler de âlimlerin çoğu, onu dinî bir delil olarak benimseyip kullanmıştır. ${ }^{82}$ Aslında kıyası reddeden gruplar ya garip hükümlerle sonuçlanacak görüşler ortaya atmışlar, ya da kıyasa anlam olarak eşit olan başka deliller kullanmışlardır.

Hz. Peygamber, direkt vahiy aldığ 1 için, onun ictihada ihtiyac1 yoktur. Şayet ictihat etse de vahiy onu düzelttiği için, bu ameliyeye terimsel anlamda ictihad denilemez. Üstelik yenilenen olaylar, vahiy ile hüküm altına alınmakta ve İslam, her geçen gün kemale ermektedir. Hz. Peygamber döneminde onun huzurunda yapılıp yapılmaması tartışılsa da, ondan ancak uzakta yaşayanlar ictihat yapma

77 Nisâ, 4/115.

78 Ebu Davud, Fiten, 1; Darimi, Mukaddime, 8.

79 Abdülkerim Zeydan, el-Veciz fi Usûli'l-Fıkh, Müesseseletü’r-Risale Naşirûn, 1. bs., Beyrut, 2014, s. 169,172, 178; bkz. Hayreddin Karaman, İslam Hukuk Tarihi, 22. bs., İstanbul, İz Yayıncilik, 2016, s. 65-68.

80 Bkz. el-Mahallavi, a.g.e., s. 178; Muhammed Ebu Zehra, Usulu'l-Flkh, el- Kahire, Daru'l Fikril-Arabî, t.y., s. 204.

81 Bkz. Abdülkerim Zeydan, el-Veciz fi Usuli'l-Fikh, s. 183,189, 200-206; bkz. Muhammed el-Emin b. Muhammed el-Muhtar eş-Şınkıti, Müzekkiretün fi Usuli'l-Fıkh, 5. bs., el-Medinetü'l-Münevvere, Mektebetü'l-Ulûm ve'l-Hikem, 2001, s. 291.

82 Abdülkerim Zeydan, el-Veciz fi Usûli'l-Fıkh, s. 207. 
durumunda kalabiliyorlardı. Nitekim Muaz'nn, Yemen'e gönderilmesi olay1, ${ }^{83}$ bunu açıkça göstermektedir. ${ }^{84}$

Kanaatimizce istishab, örf, maslahat-1 mürsele, sedd-i zerai gibi delillerin hepsi, ictihat kapsamında görülebilir. Üstelik bunlar, kaynak açısından ikincil delillerdendir. Bunlarda ittifak da edilmemiştir. Zaman ve şartların gelişmesiyle bu deliller, birer yardımcı malzeme olarak ortaya çıkmıştır. Nihayet bunların tamamında kitap ve sünnetin genel prensiplerine ve İslam'ın ruhuna aykırılık olmama şartı aranmaktadır.

Öyleyse dini hükümlerin delillerini bütünüyle nass ve ictihad ikilisi içerisinde görebiliriz. Nass, kitap ve sahih sünnet, ictihat ise nassın kapsamı ve içeriğinden çıkmamak şartıyla bütün bu zikredilen delillerdir.

Yukarıda Kur'an ve sünnet ile sabit hükümlerin dinin özünden sayılmayacağ1 iddia edildi. Böyle bir iddianın ilmi ve akli bir izahı mümkün değildir. Zira İslam dini, kitap ve sünnet eksenlidir. Bunların hücciyeti, bütün Müslümanlarca malum ve müsellemdir. Bunların dışında İslam adıyla bir dinin ispatı nasıl mümkün olabilir ki?! Oysa ki, kitap ve sünnet esasına dayanan hükümler dinin özünden sayılmazsa, bu durumda akıl yoluyla sabit olan şeylerin itibara alınması gerekir. Bunun üçüncü bir şıkkı yoktur. Peki, kitap ve sünnet merkezli ictihat-ki kapsamında akli yorum da bulunmaktadır- kınandığı halde, nasıl oluyor da soyut akıl, din konumuna yükseltilebiliyor?

Hukuku, maslahat ve makâsid bahanesiyle dinden ayırmanın ${ }^{85}$ doğru bir ispat1 görünmemektedir. Zira lafızların dışına taşan, -icabında- onlarla taban tabana zitlık oluşturan makâsid, soyut olmaktan öte bir şey ifade etmediği gibi; nasstan ayr1 ve kişilere göre değişebilen maslahatlar da kendi başlarına bir delil olamaz. $\mathrm{Bu}$ durumda objektiflik nasıl elde edilecektir? Maslahatlar arası çatışmalarda hangi ölçütte uyulacaktır?

Hukukun dinden sayılıp kıyas yoluyla naslara bağlanmasının donukluğa ve geriliğe yol açtığ ${ }^{86}$ anlayışı, temelde yanlış ve eksik bir iddiadır. Zira İslam tarihinde İslam hukuku gölgesinde bir çok medeniyetlerin ve devletlerin kurulduğu, ayrıca bir çok bilgin ve filozofun yetiştiği ve dolayısıyla bir çok ilmi ve felsefi eserlerin mevcudiyeti, bu iddiayı çürütmektedir.

83 Ebu Davud, Akdiye, 11; Tirmizi, Ahkam, 3; Nesai, Hudud, 11; İbn Mace, Menâsik, 38; Darimî, Mukaddime, 30.

84 Bkz. İzmirli İsmail Hakk1, a.g.e., 1/263-264.

85 İlhami Güler, Dine Yeni Yaklaşımlar, 3. bs., Ankara, Ankara Okulu Yayınları, 2016, s. 71-72.

86 İlhami Güler, a.g.e., 73. 
Kanaatimizce gerileme ve donukluk, İslam dininin yahut ona bağlantılı olan hukukun bir eseri olmayıp insan unsuruyla direkt alakalıdır. Burada hukuku dinden ayrı tuttuğumuzda, hukuk, kendi başına nasıl bir konum üstlenecektir. Acaba onun oluşum ve gelişim aşamasında bir çok eksik ve yanlışlar, hatta gerileme ve donukluklar bulunmayacak mi?

Hukukta kıyas yolunun işletilmesi, aslında hukuku donukluktan ve gerilikten kurtaran bir unsurdur. Ancak hukuk, dinî bir hüviyet alınca modern ve tarihselci anlayış, onu bir ayak bağı kabilinden görmektedir. Aslında bu mantığa göre beşeri hukukta da asla kıyas delilini kullanmamak gerekirdi. Oysa ki böyle bir durumda hukukun bir çok işlevselliği ortadan kalkmış olur.

\section{B. Kuralcılık Sorunu}

$\mathrm{Bu}$ argümana göre fakihler dine ahkam zaviyesinden bakmışlardır. Oysa bu helal ve haramı tahdit eden kurallar, ne Kur'an'da ne de Hz. Peygamber döneminde mevcuttur. Ortaya konan bu kurallar, tedrici olarak bütün nassla ilgili muamelelerde bağlayıcı rol oynamıştır. Öyle ki artık nasslar, fikhi gelenek olmadan anlaşılmaz sayılmıştır. ${ }^{87}$

Kural, (kaide usûl, kaide-i nazariye, ing. rule) doğru sonuç alabilmek için tutulması gereken yol, yapılması gereken anlamını dile getirir. Yasa ve ilke terimleriyle karıştırılmamalıdır. ${ }^{88}$

Aslında kural, herhangi bir meseleyi ispat ya da iptal etmiyor, aslında teorik olarak onun düzgünce anlaşılmasına aracı oluyor. Kural, tikel olayları ortak bir noktada buluşturma ve onları daha yararlı ve pratik hâle getirmekten ibarettir.

Tedvin asrıyla başlayan ilmi çalışmalar, birer kurallaştırma hareketidir. İlmi meseleler tanımlanmış, kısımlara ayrılıp gaye ve özellikleri izah edilmiştir. Nihayet branşlaşan ilimler, birçok yeni terminoloji üretmiş ve her terminoloji, alanı içerisinde kendine yüklenen anlam ve içeriklerle değerlendirilmiştir. Onun için terminolojiler arasında çatışma söz konusu değildir. Bir sözcüğün sözlük anlamı, kullanımı, geçirdiği anlam evreleri, örfi, şer'i yahut ait olduğu ilmi anlam, birçok eserle çeşitli asırlarda izah ve ispata konu olmuştur.

İslam fikhının da tedvin ile başlayan böyle bir evreyi ihmal etmesi düşünülemez. Aksi halde bu durum, bir eksiklik ve yetersizlik sayılacaktı. Bundan dolay1, fakihler, Kur'an ve sünnetten aldıkları delilleri, gerektiğinde ictihatlarıyla birleş-

87 Nâdir Hammâmi, Íslamu'l-Fukahâ, 1. bs., Beyrut, Dâru't-Talia, 2006, s. 121-122.

88 Orhan Hançerlioğlu, Felsefe Ansiklopedisi Kavramlar ve Akımlar, 4. bs., İstanbul, Remzi Kitabevi, 2005, 3/344. 
tirerek fıkıh babları oluşturup bunları, bulundukları ilim ve kültür havzasının dili ve algısı ile açıklayıp şerhetmişlerdir.

Asırların bilgi ve tecrübesini ihtiva eden binlerce cilt dolusu fikhi malumatı, bir sözcük ile sözüm ona, kuralcılıkla itham edip onları tarihin karanlık bir köşesine atma girişiminin ilmi bir tanımı olamaz. Böyle bir algıyla hareket edildiğinde öncekilerin örneğin, tıpla ilgili hayati önem taşıyan bilgilerini de atmak gerekmez mi?! Bilgi olma açısından fikıh ile tıp arasında ne gibi bir fark vardır? Bu fikhi malumatı bir köşeye attığımızı varsaydığımızda, bunun yerine koyacağımız yeni fikıh bilgileri, nasıl bir konumda ve kalitede olacaktır? Oysa ki öncekilerin mezkur bilgileri, doğru nakillerle alınıp bunlara yeni ictihatlar eklenirse ve böylece sonraki nesillere aktarılsa bu, daha doğru bir hareket tarzı olacaktır kanaatindeyiz. Asıl ilmi emanet de bunu gerektirmektedir.

Diğer yandan fakihlerin dine ahkam zaviyesinden bakması, gayet doğaldır. Zira fikıh, ameli hükümleri konu edinen bir ilim dalıdır. Haramı helali tahdit eden kuralcılık iddiası, fakihlere ve fikha karşı önyargıyı göstermektedir. Zira fakih, yukarıda da belirtildiği üzere sabit, açık ve kesin nassları tevil etme yetkisinde olmayıp nassların ihtimalli alanlarında ya da hakkında hiç nass bulunmayan olaylarda hüküm arayışına gider. Tabi ki buradaki fakihten maksat müctehittir. Müctehidin şartları ve özellikleri uzun uzadıya usûl kitaplarında anlatılmaktadır ${ }^{89}$ İctihat ehliyeti taşımayan ve ismen müctehit olanlara zaten itibar edilmez. Şurası unutulmamalıdır ki müctehit, bu yetkisini nassın kendisinden alır. ${ }^{90}$

Aslında tedvin asrıyla başlayan fikıh ve usulûn temelleri, Hz. Peygamber döneminde atılmış, hatta esas itibariyle tamamlanmıştır. Bilindiği üzere hükümler, Kur'an temelli olarak Hz. Peygamber aracılığıyla uygulanıyor ve Hz. Peygamber'in bulunmadığı yerlerde ictihatla meseleler hallediliyordu. Bu ictihat ise bazen ferdi, kaliyor bazen de ittifakla kabule mazhar oluyordu. ${ }^{91}$

Hz. Peygamber döneminde ferdi ve ictimai hayatı düzenleyen kaide ve hükümler, iki şekilde ortaya çıkıyordu:

1.Hüküm gerektiren hadiseler oluyor yahut sahabeyi, Hz. Peygamber'e başvurup sual sormaya iten problemler ortaya çıkıyordu. Bu durumda ya ayet nazil oluyor; yahut hüküm ve mana Hz. Peygamber'e vahyediliyor, $\mathrm{O}$ da kendi üslû-

89 Gazzalî, a.g.e., s. 635.; el-Mahallavî, a.g.e., s. 321.

90 Nisa 4/59; Tevbe, 9/122.

91 Karaman, İslam Hukuk Tarihi, s. 56. 
buyla hükmü açıklıyordu (sünnet). Bazı durumlarda ise hüküm, O’nun ictihadına birakı1lıordu. Kur'an'da "senden soruyorlar" ifadesi onbeş defa geçmiştir. ${ }^{92}$ Bunların sekizi, fikıhla ilgilidir. ${ }^{93}$ İki defa da " senden fetva istiyorlar " ifadesi kullanılmıştır. ${ }^{94}$

2. Hükmün vazedilmesini gerektiren bir durum olmadan, zamanı geldiğinde müstakil olarak hüküm ve kaide vazediliyordu. Aile ve ceza hukuku ile ilgili bazı hüküm ve kurallar, bu kısım içinde yer alır. ${ }^{95}$

Kur'an, hüküm beyan ederken farklı üslûplar kullanmıştır. Bu, onun mu'ciz oluşu ve hidayet ve irşadı gözetmesinin bir neticesidir. Zira Kur'an, beşeri anlamda bir hukuk, iktisat, sosyoloji vs. kitabı değildir.

Helal ve haram konusu, teklifi hükümle alakalı olduğu için, özellikle onun tanımı, kısımları ve bunların Kur'an üslubuna ne derece uyum sağlayıp sağlamadığını incelememiz de yerinde olacaktır.

Teklifi hüküm terim olarak, mükelleften bir şeyin yapılmasını ya da terk edilmesini veya iki şey arasında muhayyer kalmasını gerektiren bir hitaptır. Teklifi denilmesi, muhatabın sorumluluğuna işarettir. Sorumluluk dairesinde zorluğun bulunması da kaçınılmazdır. Mübahda zorluk olmadığı hâlde, onun teklifi hükümden sayılması, terimdeki tolerans ve tağlipten ya da mübahın, sorumlu kişiye ait olmasından dolayıdır. ${ }^{96}$ Cumhura göre bu hükümler beş kisımdir.

1.Vacip yani farz; kanun koyucu Allah'ın, mükellef olan kişiden, bir şeyi yapmasını kesin bir yolla istemesidir. Mükellef bu fiili icra etmediğinde kınanır ve böylece ahirette azaba uğrar. ${ }^{97}$ Farz, sözlükte, kesmek, tesir etmek, takdir etmek, gerekli kılmak, tahsis etmek ve kocamak anlamlarında kullanılmaktadır. $\mathrm{Bu}$ bağlamda şer'i mirası öğreten ilme "feraiz" denilmiştir. Nehrin su alınmak için ayrılan yarık kısmına da furdatü'n-nehr denir. ${ }^{98}$

Kur'an'da fard/farz sözcüğü ve türevleri; helal, meşru kılma, tayin ve takdir etme, niyet etme, gerekli ve farz kılma anlamlarında kullanılmıştır. Üslûp olarak,

92 Bakara, 2/189, 215, 217, 219, 220, 222; Maide, 5/4; Araf 7/187; Enfal 8/1; İsra 17/85; Kehf 18/83; Taha, 20/105; Naziât, 79/42.

93 Bakara, 2/215, 217, 219, 220, 222; Maide, 5/4; Enfal, 8/1.

94 Nisa, 4/127, 176.

95 Hayrettin Karaman, İslam Hukuku Tarihi, s. 54.

96 Abdülkerim Zeydan, el-Veciz fi Usûli'l-Fıkh, s. 28.

97 Abdülkerim Zeydan, el-Veciz fi Usûli'l-Fıkh, s. 27-31.

98 Muhammed b. Ebi Bekr b. Abdilkadir er-Razi, Muhtaru's-Sihah, 7. bs., el-Kahire, el-Matbaatü'l-Emiriyye, 2953, s. 498; Bakara, 2/183; Nisâ, 13; Talak, 2. 
emir kipi, fiilin yazılı olduğu, yapıldığında mükafatın gerekeceği gibi anlatımlar, ${ }^{99}$ farza delâlet etmektedir. ${ }^{100}$

Sünnette de farada, furida, farrada, ifterada, farida, farâid ve türevleri kullanılmıştır. ${ }^{101}$ Bunlarda takdir etme anlamı olduğu gibi vacip ve gerekli kılma anlamları da bulunmaktadır. Nitekim zekatta, farz olarak alınan deveye farida denilmiştir. Öyle ki zekatın dışında deve o isimle yani farida ile anılmaya başlamıştır. ${ }^{102}$

Demek ki Yüce Allah'ın bizzat Kur'an'da yahut Hz. Peygamber vasitasıla yapılmasını emir buyurduğu dinî bir hüküm, farklı üslup ve kalıplarla -ki bunlara yukarıda kısmen işaret edildi- ifade edilse de farziyete delâlet etmektedir.

2. Mendub, kanun koyucunun, kesin bir yolla olmayarak mükelleften yapılmasını istediği bir fiildir. Yapıldığında sevap kazanılan ama terkedildiğinde ceza gerektirmeyen bir husustur. Şu var ki, bazı mendup çeşitlerini terketmede kınama söz konusu olabilir. Nafile, müstahab, tetavvu, ihsan, sünnet, fazilet tabirlerinin tamamı, mendubun anlamına yakın ifadelerdir. Buna göre mendub, kendi içinde farklı derecelere ayrılmış olmaktadır.

Burada dikkat edilmesi gereken husus, mendubun bütünüyle, farza bir mukaddime olması ve mükellefi buna hazırlamasıdır. Buna ilave olarak mendub tekil olarak gereklilik ifade etmese de bütün olma hasebiyle gerekli olabilmektedir. Örneğin ezan, cemaatle namaz kılmak, nafile sadaka vermek, topluca terk edildiğinde bu durum, meşru sayılmaz. ${ }^{103}$

Nedb, sözlükte, bir şeye çağırma, ağıt yakma (nüdbe), hafif olma (nedb), yaranın izi ve tehlike (nedeb) anlamlarında kullanılmaktadır. ${ }^{104}$ Kur'an'da kesinlik ifade etmeyen emir ile özendirme üslûp ve kalıpları menduba delâlet etmektedir. Kur'an'da mendub yahut nedb ile ilgili lafizlar bulunmamaktadır. Ancak mendub kapsamında sayılan sadaka, tetavvu vb. tabirler, Kur'an'da geçmektedir. ${ }^{105}$ Nedbin hafiflik anlamında olmas1, onu farzın bir alt derecesinde kabul etmeyi sözlük açısından gerektirmektedir. Sünnette ne-

99 Bkz. Bakara, 2/197, 237; Nûr, 24/1; Ahzâb,33/38; Tahrim, 66/2.

100 Şakir el-Hanbelî, Usuûlu'l-Fıkh, 1.bs., Mekke, el-Mektebetü'l-Mekkiyye, 2002, s. 64-66.

101 Buhari, Enbiya, 5; Müslim, İman, 259; Buhari, Zekat, 1; Ebu Davud, Zekat, 5; İbn Mâce, İkame, 202; İbn Mâce, Feraid 10; Ahmed b. Hanbel, 1/313.

102 Bkz. Concordance, 5/111-118; İbnu'l-Esir, en-Nihaye, 2/359.

103 Abdülkerim Zeydan, el-Veciz fi Usuli'l-Fıkh, s. 37-39.

104 İbn Fâris, a.g.e., s. 984; Ebu Bekr er-Razi; a.g.e., s. 651.

105 Bakara, 2/158, 1639841271; Nisa, 4/114. 
debe, intedebe ve nedeb şeklinde mendubun kendisinden türetildiği tabirler kullanılmıştır. Ancak bunlarda terimsel anlam değil, sözlük anlamları söz konusudur. ${ }^{106}$

Necid'li birinin Medine'ye gelip Hz. Peygamber'e İslam'ın mahiyetini sormasıyla ilgili rivayette ${ }^{107}$ namaz, oruç ve zekat gibi farizalarla beraber nafilenin istisnai olarak zikredilmesi hususu, mendubun yukarıdaki tanımını anlamca pekiştirmektedir.

3. Haram, kanun koyucu Allah'1n, mükeleften bir şeyi terketmesini kesin bir yolla istemesidir. O fiili terkeden mükafat alır, yapan ise isyan edip günah işlemiş olur. Haram kılınan bir şey, özüyle bir mefsedet olabildiği gibi, genel yapısı itibariyle de bu konumda olabilir. Haram, li zatihi ve li ğayrihi kısımlarına ayrılır. Birincisi, başlangıçta aslı itibariyle haram iken, ikincisi Cuma ezanı saatinde alış veriş yapmak gibi başka bir şeyden dolayı haram kılınmıştır. ${ }^{108}$ Haram sözlükte engelleme ve zorlayıp sıkma anlamında olup, helal'ın karşıtıdır. Harîm evin içi ve aile, mahrem ise kendisiyle evlenilmesi yasak olan yakın akrabadır. Ayetteki haram, hirmun şeklinde de okunmuştur. Henüz sert, yumuşak olmayan kırbaç ve kamçıya da muharrem denir. ${ }^{109}$

Kur'an'da haram, harrame, hurrime sözcükleri, bizzat terimsel anlamda kullanılmaktadır. ${ }^{110}$ Haramlığa işaret eden üslûp yukarıda anlatıldığ 1 için ona temas edilmeyecektir. Sünnette harume, harrame, hurmet, muharreme ve haram sözcükleri, terimsel anlamda kullanılmıştır. ${ }^{111}$

4. Mekruh, terk edilmesi, yapılmasından daha uygun olan yahut kanun koyucu Allah'ın, mükelleften bir şeyi yapmamasını kesin olmayan bir ifadeyle istemesidir. Onu yapan günah işlemiş olmamakla beraber, kınanmış olur.

Mekruh, sözlükte kerihe kökünden gelmekte olup sevgi ve rızaya aykırılığı ifade eder. Kurh zorluk, kerh bir şeyi istemeyerek yapma zorunda kalmaktır. Kerahiyye ve kerihe, kurhtan olup savaştaki zorluğa delâlet eder. Başını dik tutup sahibine itaat etmeyen deveye de kerh denir. ${ }^{12}$

106 Bkz., Concordance, 6/390; İbnu'l-Esir, en-Nihaye, 2/724.

107 Buhari, İman, 34; Müslim, İman 8; Ebu Davud, Salat, 1; Tirmizi, Zekat, 2; Nesâi, Salat, 4.

108 Abdülkerim Zeydan, el-Veciz fi Usûli'l-Fikh, s. 39-41.

109 İmam Halil, a.g.e., s. 185; İbn Faris, a.g.e., s. 238.

110 Bakara, 2/275; Al-i İmran, 3/50; Nisa, 4/23, 160; En'am.

111 Bkz. Concordance, 1/451-457; İbnu'l-Esir, a.g.e., 1/364-362.

112 İbn Faris, a.g.e., s. 890; Ebu Bekr er-Razi, a.g.e., s. 568. 
Kur'an'da kerihe, karrehe ve türevleri ile kerh, kurh ve mekruh tabirleri geçmektedir. Sözlük anlamlarına uygun kullanılmıştır. Ancak bazen kerâhet, harama delâlet ettiği gibi; onun alt sınırı olan mekruha da delâlet edebilmektedir. ${ }^{113}$

Sünnette kerahe, kerahiye, mekreh, mekârih, mekruh, kerih ve müştakları, zor, hoş olmayan kötü ve istenilmeyen şeyler anlamında kullanılmıştır. ${ }^{114}$

5. Mübah; kanun koyucu Allah'ın, mükellefi bir şeyi yapıp yapmama arasında serbest birakmasıdır.

Kur'an'da doğrudan doğruya mübah ile kök aslı (بو احة) bavaha'dan, (اباح) ebaha ve türevleri kullanılmamıştır. Ancak hill sözcüğü, günahın nefyedilmesi, vücûbu engelleyici karine ile beraber kullanılan emir siğası türü kullanımlar, bu hususa işaret etmektedir.

Burada şunu da vurgulamak yerinde olur. Mübah ferdi anlamda yapılıp yapılmaması caiz olsa da bütünsellik açısından farklı hükümler intac edebilir. Örneğin mükellef, yemek yemeyi devamlı terk ettiğinde hayatını tehlikeye sokmuş olur ki bu durum harama yol açar. ${ }^{115}$ Mübah, sözlükte bahave kökünden gelmekte olup genişlik, açık olma ve açığa çıkma anlamlarındadır. Bûh, bâhe'nin çoğuludur, bir şeyin ortası demektir. Bu bâbtan olarak ibâhe sakıncalı olmayan darlık ve sıkıntı oluşturmayan şeyde kullanılır. İstebahe, bir şeyi yağma etmek, kökünden söküp almaktır. ${ }^{116}$ Sünnette bâhe'nin türevleri yebûhu, ebâhe, istebâhe, bavah ve bahetün sözcükleri kullanılmıştır. Bunlarda sözlük anlamlarıyla beraber, haramın karşıtı helal olma durumu da kastedilmiştir. ${ }^{117}$

Cumhura ait terimleri gördükten sonra Hanefilerin teklifi hükümlere ilave ettikleri vacib ve tahrimen mekruh tabirlerini incelemeye çalışalım. Hanefiler farz konsunda delili zanni olanları vacip, haram konusunda ise bu konumda olanlar1 tahrimen mekruh saymaktadırlar. Bu meyanda cumhur, hükmün mükellefleri bağlayacılığını esas alırken, Hanefiler -görüldüğü üzere- delilin subut ve kuvvet derecesini esas almaktadırlar. ${ }^{118} \mathrm{Bu}$ durum, haram hükmünde ihtiyatlı bir duruşu sergilemektedir.

113 Bakara, 2/216; Enfâl, 8/87; Âl-i İmrân, 3/83; Ahkâf, 46/15; Hucurât, 49/12; Tevbe, 9/81; Muhammed (a.s) 47/26; İsrâ, 17/38.

114 Concordance, 6/6-7; İbnu'l-Esir, a.g.e., 2/537.

115 Eş-Şatıbi, a.g.e., 1115-113/; Abdülkerim Zeydan, el-Veciz fi Usûli'l- Fıkh, 45; Muhammed Ebu Zehra, Usûlu'l-Fıkh, el-Kahire, Daru'l-Fikri'l-Arabî, t.y., s. 42.

116 İbn Fâris, a.g.e., s. 143; Ebu Bekr er-Razî, Muhtaru's- Sihâh, s. 68.

117 Concordance, 1/231; İbnu'l- Esir, a.g.e., 1/163- 164.

118 Abdülkerim Zeydan, el-Veciz fi Usul, s. 31. 
Aslında vacip farz kapsamında, tahrimen mekruh da haram kapsamında mütalaa edilmektedir. Aralarındaki fark, delili kesin olanın inkarı küfrü gerektirirken, delili zanni olanın inkarının bunu gerektirmemesidir. Bundan böyle Hanefilerin cumhuru vacibe "ameli farz" demişlerdir. Cumhur ile Hanefiler arasındaki ihtilafin bazı neticeleri olsa da temelde bunun hakiki olmayıp itibari olduğu, bazı alimlerce dile getirilmiştir. ${ }^{119}$

Vâcib, sözlükte vecebe yecibu/vucûben'den ism-i faildir. Gerekli olmak, düşmek, meydana gelmek, ölmek, güneşin batması, günde bir öğün anlamlarına gelir. ${ }^{120}$ Sünnette vecebe, ecâbe, evcebe, istevcebe, vacib, mûcibetün, mûcibâtün, vecbetün ve vucûb sözcükleri kullanılmıştır. Bunlardan bir kısmı, farz anlamında anlaşılsa da terimsel anlamındaki vâcip mezkur ifadelerden anlaşılmamaktadır. ${ }^{121}$

Yukarıda helal ve haramla ilgili olarak anlatılan teklifi hüküm, -görüldüğg̈ üzere- kitap ve sünnet çerçevesinde ortaya atılan kuralları ihtiva etmektedir. Tahrimen mekruh, haramın aslını değiştirmediği gibi, vacib de farzı iptal etmemiştir. Bazı terimlerin Hz. Peygamber döneminde olmaması, söz konusu terimlerin içerik açısından o dönemde bulunmamasını gerektirmez. Hiçbir müslüman âlim, kesin ve açık olan farzda yahut da haramda ihtilaf ortaya koymaz ve bu yetkiye de sahip değildir. Zira Yüce Allah buna şöyle işaret etmektedir: "Dillerinizin uydurduğu yalana dayanarak 'Bu helâldir, şu haramdır' demeyin. Çünkü Allah'a karşı yalan yere iftirada bulunmuş olursunuz. Allah'a karşı yalan yere iftirada bulunanlar, kurtuluşa eremezler." 222

\section{Fıkhi İhtilaflar}

Tarihselcilere göre fikhi ihtilafları, salt nassın yorumsallığına bağlamak mümkün değildir. Zira bunlar, temel meselelerde zaman ve şartlara göre değişen ve nassın kapsamından çıkan bir yapıda görünmektedir. Dolayısıyla fakihlerin güvenirliklerini kaybettiklerine dair birçok delil ve rivayet bulunmaktadır. ${ }^{123}$

İhtilaf, sözlükte halefe kökünden gelmektedir. Bununüç anlamı bulunmaktadır: 1)Bir şeyin sonradan gelip öncekinin yerine geçmesi 2) Önün karşıtı arka- geri. 3) Değişim ve başkalaşma. Buradaki ihtilaf, birinci kısımdandır. Zira ihtilaf eden kişi, kendisini diğerinin konumunda görmek ister. Half nesil, kuşak, kötü söz.

119 Abdülkerim Zeydan, el- Veciz fi Usûli'l-Fıkh, s. 31-32; Ebu Zehra, Usûlu'l- Fıkh, s.26; bkz. el-Âmidî, a.g.e., 1/87.

120 İbn Faris, a.g.e., s. 1045; Ebu Bekr er- Razi, a.g.e., s. 709.

121 Bkz. Concordance, 7/136- 140; İbnu'l- Esir, a.g.e., 2/824- 825.

122 Nahl, 16/116.

123 Nâdir Hammamî, İslamu'l-Fukahâ, 1. bs., Beyrut, Dâru't-Talia, 2006, s. 84-86. 
Halef bir şeyin yerine geçen bedel, iyi evlat. Hulf, sözü tutmama, hilaf muhalefet ve aykır1lık. ${ }^{124}$

İhtilaf, terim olarak anlaşmazlık, delilden kaynaklanan görüş ayrılığı demektir. ${ }^{125}$ Kimine göre ihtilaf ile hilaf farklı şeylerdir. İhtilaf, müctehitlerin, hakkında kesin nass bulunmayan hususlarda ortaya attıkları farklı görüşlerdir, ama hilaf, heva ve arzudan kaynaklanan subjektif düşüncelerdir. ${ }^{126}$ Şu var ki fakihler, her iki kavram arasında bir fark görmeden aynı maksada yönelik kullanıyorlar. Üstelik sözlük anlamı açısından da böyle bir farkındalık görülmemektedir.

İbn Haldun (ö. 808-1406) şer'i delillerden ictihat yoluyla çıkarılan fikhın birçok yönde ihtilaflı görüşler ihtiva ettiğini ve bunun da belirtilen gerekçelerden ötürü zorunlu olduğunu söylemektedir. ${ }^{127}$ Anlaşıldığg üzere âlimler arasındaki ihtilaflar, dini açıdan çoğunlukla fikıh alanında olduğu için, bu konuda münazara ve cedel ile hilaf ilmi doğmuştur. ${ }^{128}$

Yüce Allah, dinleri konusunda firkalara ayrılan, parçalanıp dağılanları k1nayıp özellikle kendi ipine sımsıkı sarılmayı emrettiği ${ }^{129}$ hâlde, bu söz konusu ihtilafları nasıl değerlendirmemiz gerekmektedir? Acaba, bunlar Allah'ın yasakladığı alanlara mı giriyor, yoksa bunların dinî nasslardan meşru bir dayanağı bulunmakta midir?

Aslında insanların renk, dil ve şekil olarak farklı yaratılışları, ${ }^{130}$ anlayış ve kavrayış açısından aynı derecede olmamaları, ihtilafı bir yönden meşru kılmaktadır. Ancak bu ihtilaf, mutlak olmayıp her zaman ve zeminde gerçekleşecek anlamina da gelmemektedir.

Yüce Allah, insanları kulluk göreviyle sınadığı için onları tek bir din ve inanç üzerinde birleştirmemiştir. Şayet öyle olsaydı, sınamanın bir hikmeti ve anlamı kalmazdı. Buna Kur'an'da şöyle işaret edilmektedir: "Rabbin dileseydi bütün insanları, bir tek millet yapard1. Onlar ihtilafa düşmeye devam edecekler. Ancak

124 İbn Fâris, a.g.e., s. 309; Ebu Bekr er- Razî, a.g.e., s. 185-186.

125 Mehmet Erdoğan, Fıkı ve Hukuk Terimleri Sözlüğü, 5. bs., İstanbul, Ensar Neşriyat, 2015, s. 237.

126 Abdülkerim Zeydan, el-Veciz fi Usuli'l-Fıkh, s. 387-888; eş-Şatıbi, a.g.e., 2/576; Muharrem Kılıç, "Hukuki Görüş Ayrılıkları (İhtilaf) Ve Hilafa Riayet (Mürââtü’l-Hilaf) İlkesi Konusunda Şâtıbi’nin Yaklaşımı”, Marife, yı1 5, sayı 2, Güz 2005, s. 55-73.

127 Abdurrahman b. Muhammed b. Haldun el-Hadrami, Mukaddime, Beyrut, Daru'l-Ceyl, t.y., s. 505.

128 Siddık Han el-Kannûcî, Ebcedu'l-Ulûm, Beyrut, Dâru'l-Kütübi'l-İlmiyye, h.1398, 2/18.

129 Âl-i İmran, 3/103,105; Nisâ, 4/157; Enfâl.

130 Rûm, 3022/. 
Rabbi'nin merhamet ettikleri müstesna. Zaten Rabbin onları bunun için yarattı. Andolsun ki cehennemi tümüyle insanlar ve cinlerle dolduracağım sözü yerini buldu!"'131

Hak ve batıl din ve inançlar arasında ihtilaf zorunlu olmakla beraber, hak bir din içerisinde bu tür bir ihtilaf, asla caiz değildir. Bu konuda şöyle buyurulmaktadır: "Ayrılığa düştüğünüz herhangi bir şeyde hüküm vermek, Allah’a aittir." 132 "Şayet herhangi bir şeyde anlaşmazlığa düşerseniz, Allah'a ve ahirete gerçekten inanıyorsanız, onu Allah'a ve Resûl'e götürün; bu hem hayırlı hem netice bak1mindan daha güzeldir."133

Öyleyse İslam fikhındaki ihtilaf, yukarıda zikredilen her iki tür ihtilaftan/ tefrikadan farklı bir boyutta seyretmektedir. Bunun ispatını şöyle izah etmek mümkündür. Yüce Allah, insanları, fetret döneminden sonra Hz. Muhammed (a.s) aracılığıly Kur'an vahyiyle muhatap kı1dı. Kur'an kendini tebliğ etme göreviyle gönderilen zat tarafindan eksiksiz beyan edildi ve bizzat 22 küsur yılda çeşitli olay ve sorunlara karşılık verecek bir yapı ve özellikte uygulatma süreci yaşadı. Bu konumda olan bir kitabın sonraki nesillere aynı yapı ve özellikte aktarılmas1, akıl ve nakil açısından bilinen bir husustur. Aksi hâlde Kur'an'ın sonraki nesillere hiç aktarılmadığı ya da eksik aktarıldığı sorunu ortaya çıkar. Nitekim Kur'an'ın kendisi bu hususa bir çok ayetle işaret etmektedir. 'Kur'an'1 kesinlikle biz indirdik: elbette onu yine biz koruyacağız. "134 "Hâlâ Kur'an üzerinde gereği gibi düşünmeyecekler mi? Eğer o, Allah'tan başkası tarafindan gelmiş olsaydı, onda bir çok tutarsızlık bulurlard.." ${ }^{135}$

Yüce Allah, Hz. Peygamber ile beraber bulunan kuşağı tezkiye etmiş, onları övmüş ve onlardan razı olduğunu bildirmiştir. " Öne geçen ilk muhacirler ve ensar ile onlara güzellikle tabi olanlar var ya, işte Allah, onlardan razı olmuştur. Onlar da Allah'tan razı olmuşlardır.." ${ }^{\prime 36}$ Demek ki Hz. Peygamber dönemini temsil eden kuşağın sonraki kuşaklara aktardığı ilahi vahiy ve onun beyanı ve uygulaması olan sünnet, aslı itibariyle kaynaklık açısından müsellem olmak durumundadır. Aksi halde, bütün Müslümanların mütevatir kabul ettikleri Kur'an'ın, temel kaynak olma olgusu, bu anlamıyla sorun oluşturur. Çünkü Kur'an'daki mücmeli beyan, ancak sünnet ile mümkün olmaktadır.

131 Hûd, 12118/.

132 Şûra, $4210 /$.

133 Nisâ, 4/59.

134 Hicr, $15 / 9$.

135 Nisâ, 4/82.

136 Tevbe, $9 / 100$. 
Prensip olarak böyle olmakla beraber, şunu unutmamalıyız ki sünnetin Kur'an gibi topluca yazılmaması ve Kur'an lafzı gibi aynı özenle aktarılmaması, rivayetin keyfiyeti açısından bazı sorunlar oluşturmaktadır. Tabi ki bu durum, sünnetin bütününe değil, onun tikel yönüne nispetledir. Elbette ki bunun birçok hikmetleri bulunmaktadır. Sünnetin derece olarak Kur'an konumunda olmaması, Kur'an'la Peygamber sözlerinin karışma tehlikesi, yazı malzemesinin yetersizliği ve yazı yazabilen kişilerin azlığı bunlardan bir kaçıdır. Ancak bu sayılan gerekçelerin hiçbiri, külli anlamda sünnetin kaybolduğunu ve beyan olma nitesiyle sünnetin eksik aktarıldığını göstermez. Böyle bir iddia, Kur'an'ın kendisiyle çelişir: "Alemlere uyarıcı olsun diye kulu Muhammed'e furkanı indiren Allah, yüceler yücesidir.” 137 “...İnsanlara kendilerine indirileni açılaman için ve düşünüp anlasinlar diye sana da Kur'an'1 indirdik." 138

Kur'an'1 anlamaya ve onu uygulatmaya yönelik ihtilaf, Hz. Peygamber döneminde de olabiliyordu. Ancak Hz. Peygamber'in varlığ1 ve otoritesi, bunları anında çözüyor ve nihayette olay, vahiyle hüküm altına alınıyordu. Halifeler döneminde de ortaya çıkan ihtilaflar, kitap ve sünnete havale edilerek resmi otorite tarafından çözüme ulaştırılıyordu. Nevzuhur olaylarda ise ictihat devreye giriyordu. Ancak olayların azlığı ile orantılı olarak ihtilaflar da az oluyordu.

Ne var ki İslam coğrafyasının genişlemesi, farklı din ve kültürlere mensup kişilerin bölük bölük İslam'a girmeleri, dolayısıyla çeşitli dini sorunların ortaya çıkması neticesinde ictihat mekanizmasının daha da işletilmesi zorunda kalındı. Çeşitli bölge şartlarında yetişen müctehitler, kendilerine ulaşan sünnet malzemesine dil, kültür ve örfi malumatları da ilave ederek bir kısım fetvalar verdiler. Elbette ki bu noktada âlimlerin aynı derecede fetva vermeleri ya da tek tip düşünce üretmeleri mümkün olmadığ 1 gibi böyle bir şey de kendilerinden istenemezdi.

Tedvin asrıyla başlayan telif çalışmalarıyla söz konusu ictihatlar, fikıh branş1 içerisinde büyük bir yekûn oluşturdu ve her asırda bunlara farklı ictihat ve görüşler eklenip zamanımıza ulaştı. Bizler, kendi zaman ve şartlarımızda bu tarihi mirasa salt kendi konumumuz açısından baktığımız zaman büyük bir yanılgıya düşeriz. Zira bu fikıh mirası, çoğunlukla içinde bulunulan dönemlerin örf, adet ve maslahatlarını yansıtmakta olup bunlar, tikel çözüm ve ihtilaflar olarak kabul edilmelidir. Bu anlamdaki her bir ihtilaf, dinin aslı gibi telakki edilip İslam dininde yahut da islam şeriatı ve fikhında ihtilaf bolluğundan dem vurmak, başından beri yanlış bir algıdır. Öyleyse İslam fikhında ictihattan kaynaklanan ihtilafları

137 Furkan, 25/1-2.

138 Nahl, 16/44. 
söz konusu ettiğimizde, önce ictihadın alanını, müctehidin konumunu ve onun sahip olduğu yetkiyi iyice tespit etmeliyiz.

İctihat, sözlükte çaba göstermek ve bir şeyi elde etmek için olanca gayret göstermektir. ${ }^{139}$ Terim olarak, müctehidin, şer'i, fer'i zanni bir hükmü, tafsili delillerden elde edip çıkarmak için olanca gücünü sarf etmesidir. ${ }^{140}$ Müctehid ise bu vasıfta olan hükmü çıkarabilme melekesine sahip olan âlimdir. Müctehit olabilmenin birçok şartları bulunmaktadır. Bunları kısaca şöyle anlatabiliriz: 1 . Arap dilini Arapların hitabını ve üslûp yapılarını anlayacak şekilde bilmek. 2 . Kur'an ve sünneti ahkâm yönleriyle hakkıyla bilmek. Burada herhangi bir metni ezberleme şartı yoktur. Ancak sünnetin rivayet derecelerini bilmesi gerekir. 3. İstinbat yollarını öğreten ilimleri, özellikle fikıh usûlünü bir meleke olarak bilmek. 4. İcma edilen hususları bilmek. 5. Şeriatın makâsidini, insanların örf, adet ve maslahatlarını, asrın ortaya atılan sorunlarını bilmek. 6. Fitri bir ictihat kabiliyeti taşımak. ${ }^{141}$

Yukarıdaki bilgiler 1şığında düşündüğümüzde ictihat, hakkında açık nass bulunan kat'i meselelerde değil, zanni meselelerde ve aynı zamanda akli, hissi ve itikadi alanlarda olmayarak, fer'i ve ameli hususlarda gerçekleşmelidir. Üstelik ictihat yetkisini haiz olmayan birinin, bu yönde ortaya atacağ görüşe itibar edilmediğine göre onun ihtilafina da haydi haydi önem verilmez.

Görülüyor ki fikhi ihtilaf, sınırları tayin edilemeyen ve herkesin dilediği gibi onda atını oynattığı bir meydan değildir. Müctehit görüş ve ictihatlarında temelde nasslardan kaynaklandığı gibi netice olarak da nassların kapsam ve içeriklerinden ayrı hareket edemez. İçtihat adıyla ortaya atılan bu nevi fetvalar, kitap ve sünnet esas alınarak eleştirilmiştir.

Daha önce anlatıldığı üzere İslam fikhı, İslam şeriatından tamamen müstakil olmayıp onun değişen durum ve şartlarda münasip bir tarzda uygulanmasından ibarettir. Külli anlamda ictihada verilen cevaz, tikel anlamda ihtilafların vukuuna cevaz kabilindendir.

İhtilafin bu anlamca meşruiyeti anlaşıldıktan sonra bunun kapsadığ bazı gerekçeleri kısaca izah etmeye çalışalım. ${ }^{142}$

139 Ebu Bekr er-Razi, a.g.e., s. 114.

140 Mehmet Erdoğan, Fıkıh ve Hukuk Terimleri Sözlüğü, s. 226.

141 Abdülkerim Zeydan, el-Veciz fi Usuli'l-Fıkh, s. 376-380.

142 M. Koçak (vd.leri), a.g.e., s. 113-135; Ahmet Yaman-Halit Çalış, a.g.e., s. 118-124; Ali el-Hafif, Ahkamu'l Muamelati'ş-Şer'iyye, el-Kahire, Daru'l-Fikri'l-Arabi, 2008, s. 12; Fahrettin Atar, a.g.e., s. 387. 
Kitap ve sünnet nassını dil açısından farklı yorumlama olgusu: Arap diliyle nazil olan Kur'an ve varit olan sünnet, delâlet açısından aynı derecede olmadığı için, bazen bir sözcügün anlamını tayin ederken ihtilaf çıkabilmektedir.

1. Örneğin, Bakara, 2/228'deki ayette geçen “üç kuru'...” sözcüğünden, hayız ya da temizliğin anlaşılması ${ }^{143}$ ve "lâ nikahe illa bi veliyyin/nikah ancak veli ile akdedilir" hadisinden ${ }^{144}$ velisiz nikahın geçersizliği yahut sadece mekruh olduğu görüşü ${ }^{145}$ gibi.

2. Hadis rivayetlerinde sihhat derecelerini tespit sorunu: Bazen de farklı bölgelerde bulunan müctehidlerden bir kısmına o konuyla ilgili rivayetin ulaşmamas1. Kimi durumda da ravilerin aktardıkları rivayeti farklı ezberlemeleri.

3. Hükmün illetini tespitte farklı düşünmeleri. Bazı hükümlerin illeti nasslarla açıkça bildirildiği hâlde, bazıları ancak müctehidlerce kıyas yoluyla tespit yoluna gidilmiştir. Örneğin, hadisteki riba konusu altı maddeden oluşmaktadır. Ancak burada ribanın illeti, miktar-cins, cins-yiyecek, cins-yiyecek ve iddihar (stoklama) olmak üzere mezhepler arasında ihtilafa neden olmuştur.

4. Bazı fer'i delillerin hüccet olup olmayacağı ile ilgili farklı anlayışlar. İstihsan, mesâlih-i mürsele, istishab, sed-i zerai-ile, Medinelilerin ameli bunlardandır. Aslında müctehidlerin bulundukları toplum yapısı, eğitim ve kültür seviyeleri de bu farklılığa yol açmıştır. ${ }^{146}$

Yukarıda sayılan ihtilaf sebepleri, dini ve ilmi açıdan meşru bir dayanağa sahiptir. Onun için bu kapsamda oluşan ihtilaflar, Müslümanlar arasında bir kınama aracı sayılmamalıdır. Müslümanlar kişisel anlamda şer'i bir dayanağa nispet edilen herhangi bir fetva ile amel edebilirler. Ancak devlet düzeni içerisinde islami hukuk söz konusu olduğunda ihtilafların asgariye indirgenmesi ve meşru bir şekilde mezhep ve görüşler arasında tevfik ve mukarenenin oluşturulması, özellikle çağımız açısından önemli görülmektedir. İhtilaf bu yönüyle doğal ve meşru olmakla beraber, ona özendirilmez ve vaki olduğunda da garip karşılanmaz. Müctehitlerin kendi ictihatlarına uymaları gerekli iken, o konumda olmayanların, ihtiyaca binaen herhangi bir müctehide uymaları caizdir. Mezhep ve meşrep ko-

143 İbn Rüşd, a.g.e., 2/105.

144 Buhari, Nikah, 36; Ebu Davud, Nikah, 19; Tirmizi, Nikah; İbn Mace,Nikah, 15; Darimi, Nikah,11; Ahmed b. Hanbel, 1/250, 394, 413, 418.

145 İbn Rüşd, a.g.e., 2/10; Muhammed b. Ali b. Muhammed eş-Şevkâni, Neylü'l-Evtâr Şerhu Munteka'l-Ahbar min Ahadisi Seyyi'l-Ahyar, thk. Isameddin Sabbabeti, el-Kahire, Daru'l-Hadis, 2005, 3/504; M. Koçak (vd.leri), a.g.e., s. 187.

146 Bkz. el-Hafif, a.g.e., 13. 
nusunda bağnazlığa düşmeden ve karş1 görüşü de tamamen batıl görmeden kendisine uıyulan bir ictihat, ${ }^{147}$ elbette ki övgüye lâyıktır.

Burada şöyle bir soru ortaya atılabilir: İslam fikhında, bir mezhebin helal dediğine, bir başkası haram ya da farz, diğeri vacip ve sünnet diyebiliyor. Din adına böyle bir hüküm algısı, nasıl caiz olabilir?

Yukarıda anlatılan ictihadın mahiyeti ve alanları iyice kavranıldığında bu sorunun cevabı kolayca anlaşılır. İslam şeriatında ihtilafın cari olmadığını daha önce anlattık. Konumuz İslam fikhı ile ilgilidir. Fıkhın kendisi, ictihada dayanması yönüyle zanni hususları kapsamaktadır. Ancak fikhi her görüş, ictihad değildir. Bundan dolayı, fikıhtaki her ihtilaf, aslında bu mana da ihtilaf sayılmaz. İctihadi ihtilaf ise alanı ve yetkili mercii tarafından yapıldığında, ortaya çıkan uzman görüşü meşru olduğundan, dini açıdan sorun oluşturmaz. Zira dinî nasslar -anlatıldığı üzere- prensip olarak ictihada izin vermiştir. Buna göre ictihat vasıtasıyla terimselleşen farz ve haram tabirleri, itikadi yönden olmayıp ameli yöndendir.

Yüce Allah boşanma konusunda şöyle buyurmaktadır: "Boşanma iki defadır. Bundan sonra ya iyilikle tutmak ya da güzellikle salıvermektir... Şayet erkek, kadını (üçüncü defa) boşarsa ondan sonra kadın bir başka erkekle evlenmedikçe onu alması kendisine helal olmaz." 148

İlgili ayette boşanma üç ile sınırlandırılmıştır. Ancak fakihler, üç sayısının bir lafızla söylenmesi durumunda bunun üç sayılıp sayılmayacağı konusunda ihtilaf etmişlerdir. Dört mezhep ulemasının başını çektiği cumhur, bunun üç talak sayılacağını belirtirken Zahirler ile Zeydiyye ve İbn Teymiyye ile öğrencisi İbn Kayyim el-Cevziyye vb. âlimler, bunun bir talak sayılacağını söylemektedirler. Her iki görüş yukarıdaki ayeti farklı anlayışlarla tevil edip bazı hadis rivayetlerini delil olarak kullanmışlardır. Ayrıca İmamiye firkası böyle bir durumda bunun bidat sayılıp talak kapsamında görülmeyeceğini ileri sürmüştür. İbn Rüşd'e göre cumhurun böyle bir uygulamaya fetva vermesi boşamaya karşı bir önlem amacı taşımaktadır. Ona göre İslam'ın rahmet anlayışı ve ayetin zahiri, ikinci görüşü desteklemektedir. ${ }^{149}$

Yüce Allah, örneğin "Vamsehû bi ruûsikum/başınızı meshedin"150 buyurmaktadır. Mezkur ayette başın tamamının mı, yoksa bir kısmının mı meshedileceği açık bir biçimde söylenmemiştir.

147 Bkz. M. Fikhi el-Ayni, Risale fi Edebil Müfti, thk. Osman Şahin, TDVY, t.y., s.109.

148 Bakara, 2/229-230.

149 Bkz. İbn Rüşd, a.g.e., 2/72-73; Muhammed Ebu Zehra, el-Ahvalu'ş-Şahsiyye, el-Kahire, Daru'l-Fikri'l-Arabi, t.y., s. 305; Şeltut-es-Sayis, a.g.e., s. 130-143.

150 Bkz. Mâide, 5/6. 
Malikiler başın tamamını, Hanefiler nâsiye (alın) miktarını/dörtte birini, Şafiiler bir kıl ya da üç kı1 miktarını farz görürlerken, Hanbelilerden iki rivayet aktarılmaktadır. Bunlardan birisi Malikilerin görüşüne, diğeri Hanefilerin görüşüne benzemektedir. Hadis rivayetlerinde de Hz. Peygamber'in hem başın tamamını, hem de bir kısmını meshettiği zikredilmektedir.

Bu ihtilafi, Arap dilinde, bâ'nın tab'iz/miktar ve zaid olarak kullanılması anlamlarında müşterek olmasından kaynaklanmaktadır. Ayetteki bâ'yı zaid kabul edenler başın tamamını meshetmeyi savunmuştur. Bu durumda, bâ pekiştirme ifade eder. Tab'iz anlamını savunanlar ise başın bir kısmının meshedileceğini ifade etmişlerdir. Nihayet bu görüşü bazı hadislerle de desteklemişlerdir. ${ }^{151}$

Oysa ki zikri geçen ayet, mutlak başın meshedilmesini söz konusu etmektedir. $\mathrm{Bu}$ durumda ister tamamı, ister bir kısmı gerçekleşsin, hüküm açısından aynı derecededir. ${ }^{152}$ İşte burada başın miktarı ile ilgili farz terimi, zanni delille ilintili olup ictihadidir. Her iki taraf da bu konuda mazur olup her bir görüş ile amel edilebilir. Zaten mutlakın anlamı da budur. Bilindiği üzere başın meshedilmesi, şer'i farz olduğu için asla inkar ve ihtilaf konusu olamaz. Ancak miktarın tayini böyle değildir.

Yine “...Eğer hasta olur veya bir yolculuk üzerinde bulunursanız yahut sizden biriniz ayak yolundan gelirse, yahut kadınlara dokunup da (bu durumlarda) su bulamamışsanız, o zaman temiz bir toprakla teyemmüm edin..." 153

Yukarıdaki ayette kadınlara dokunmaktan bahseden kısım, "ev-lâmestümü'n-nisâe" şeklinde ifade edilmektedir. Seleften Ali, İbn Abbas, Ebu Musa, el-Hasen, el-Ubeyde ve eş-Şâbi'ye göre bu tabir, cinsi ilişkiden kinayedir. Ömer ve İbn Mes'uda göre ise anlamı el ile dokunmadır. Nitekim fakihler bu konuda aynı minvalde ihtilaf etmişlerdir. Ebu Hanife, Ebu Yusuf, Züfer ve es-Sevri'ye göre kişi, ister şehvetle, ister şehvetsiz dokunsun abdesti bozulmaz. İmam Malik şehvet ile dokunmada abdestin bozulacağını ifade etmektedir. Şafiye göre ise ister şehvetle, ister şehvetsiz olsun, dokunma abdesti bozar.

$\mathrm{Bu}$ ihtilafin sebebi, lems/dokunmanın Arap dilinde elle dokunma ile cinsel ilişki arasında müşterek bir kullanıma sahip olmasından kaynaklanmaktadır. Ancak Kur'an'daki diğer kullanımlar, siyak-sibak ve Hamza ile Kisâî'nin kıraâtleri ile bu konudaki hadis rivayetleri, mezkur tabirin cinsel ilişki anlamında olduğuna açık bir karinedir. ${ }^{154}$

151 Bkz. İbn Rüşd, a.g.e., 1/26, Muhammed Ali Sayis (vd. leri), Tefsiru Ayâti'l-Ahkâm, thk. Hasen es-Semâhi Süveydân, 6. bs., Beyrut, Dâru İbn Kesir, 2012, 1/569.

152 Şeltut es-Sa'yis, a.g.e., s. 21.

153 Nisa, 9/43.

154 İbn Rüşd, a.g.e., 1/53-55. 
İlgili ayette kinaye yollu cinsel ilişkinin amaçlandığı, tercih edilmekle beraber, burada umum-1 müşterek tarikiyle her iki görüşle birlikte amel etmek ihtiyata daha uygundur. Zira elle dokunma anlamı da ayetin zahirine muvafiktır.

"Ey iman edenler! Namaz kılmaya kalktığınız zaman yüzlerinizi, dirseklerinize kadar ellerinizi, başlarınızı meshedip topuklara kadar ayaklarınızı yıkayınız."155

Yukarıdaki ayette "dirseklerinize kadar ellerinizi..." ifadesi, "ve eydiyeküm ile'l merafiki" şeklinde geçmektedir. Âlimler dirseklerin abdestte yıkamaya dahil olup olmamasında ihtilaf etmişlerdir. Cumhura göre eller dirseklerle beraber yıkanmalıdır. Zahiriler ve Maliki mezhebinden bazı sonraki âlimler ile Taberi vb.leri, dirseklerin yıkanmasının gerekmediğini söylemektedirler.

Burada ihtilafın sebebi, ayetteki "ilâ" harfi cerinin gaye ile, ma'a/ beraberlik anlamında müşterek kullanılması ve Arap dilinde yed/el sözcügünün tanımı ve kapsamındaki ihtilafa dayanmaktadır. ${ }^{156}$ Aslında "ilâ", sonrasının öncesine ğaye (ve nihai sınır) olduğunu ifade edip mezkur ğaye'nin hükmün kapsamına girmesi ya da o kapsamdan çıkması, ayrı bir delile muhtaçtır. ${ }^{157}$ Görüldügü üzere "dirseklere kadar" olan kısım, sarih olup ihtilaf konusu olmamıştır. Asıl ihtilaf, sarihin dışında, ihtimalli olan delâlet türünde gerçekleşmiştir.

Fıkhi ihtilaftan tamamen kurtulmak mümkün olmadığı gibi böyle bir şey istenmez de.Zira fikhın her çağa hitap eden doğası, bunu gerektirmektedir. Ancak ihtilaf, bazı tedbirlerle aza indirgenebilir. Şeriat ve fıkıh kavramları çerçevesinde aktarılan bilgiler ışığında bu tedbirlerle ilgili bazı kanaatlerimi zikretmek istiyorum:

1. İslam şeriatını esas alıp fikhı bütün durum ve şartlarda ona tabi kılmak. Zira ictihat, nassa bağlı kalmak zorundadır.

2. Görüş ve mezhep taassubuna düşmeden delillere göre hareket etmek. Zira delile uymamak, hevaya uymayı neticelendirir.

3. Zaman ve şartlara göre değişen ictihat ve fetvalarda içinde yaşanılan çağın konumunu göz önüne almak. Çağı tanımamak en büyük cehalettir.

4. İslam'ın temel ve genel prensiplerine aykırı görülen görüş ve fetvaları terviç etmemek.

5. İslam şeriatının sustuğu konularda, nassı zoraki yorumlarla tevil etmemek. Malumdur ki tâli ihtilafların bir çoğu, bundan kaynaklanmaktadır.

155 Mâide, 56/.

156 İbn Rüşd, a.g.e., s. 25.

157 Ali es-Sâyis (vd.leri), a.g.e., 1/568. 
6. Özellikle sünnetle delillendirme yapıldığında rivayetler arasından sıhhat derecelerini isnad ve metin cihetleriyle iyice tetkik etmek. Bu konuda zayıf, daima kuvvetli olan delile tabidir.

7. F1khi görüşler arasındaki mukayesede İslam şeriatını birer metin, mezhep görüşlerini de birer şerh kabilinden görüp metnin kapsamından uzak düşmeme hassasiyetini göstermek.

\section{Zaman Aşımı}

Tarihselcilere göre fikhi hükümler, belirli bir dönem ve geçici bir sürede oluşan hükümlerden ibaret olduğu için, salt beşeri bir birikimden ibarettir. Dolayısıyla bunlar, artık çağımıza hitap edecek kapasitede değildirler. Ayrıca fikhi hükümler, eşitsizlik ve zulüm üzerine tesis edilmiştir. Erkeğin kadına, müslümanın gayr-i müslime ve hürün köleye karşı üstünlüğü bu kapsamdadır. ${ }^{158}$

Fıkhi hükümler, nasslarla kayıtlı olmak şartıyla meşruluk kazanırlar. Zaten bu kaynaklık yönü -ki daha önce anlatıldı- onları, beşeri hukuktan ayırmaktadır. Zaman ve mekana göre değişme durumu, mutlak olmayıp yenilenen örf ve adetlerle ilgilidir. Aslında fikhın bu yönü, övünülecek bir husustur. Zaman ve mekana hitap edemeyen fikıh, donuklaşır ve çağın gerisinde kalır. Aynısı beşer hukuku için de geçerlidir. Zamana hitap edemediği durumda itibarını yitirir.

Aslında zamana hitap etme hususunda fikıh ile hukuk, aynı minvâldedir. Çünkü her ikisi de beşeri ihtiyaçlarla ilgili düzenlemeleri ihtiva etmektedir. $\mathrm{Bu}$ noktada fikhı, hukuktan aşağı görmek, kendi içersinde çelişkili görülmektedir. Ayrıca fikhın kaynak açısından nasslara dayanması, ona artı bir meziyet kazandirmaktadır.

İslam fıkhında eşitsizlik ve zulmün varlığını iddiaya gelince; İslam fıkhı, külli anlamda İslam şeriatına tabi olmakla, onun böyle bir konumda bulunması, asla tasavvur edilemez. Yüce Allah âdildir, adaleti ve ihsanı emretmekte, zalimlerden asla razı olmamakta ve onlara cehennem azabını ceza olarak vadetmektedir. Hatta zalimlere sırtını verenlere, azabın dokunacağını haber vermektedir. Bu konuda birçok açık ve kesin dinî nasslar bulunmaktadır. ${ }^{159}$

Erkeğin kadına karşı üstünlüğü, her hangi dinî bir temele dayanmamaktadır. “erkekler kadınların kavvamı/yöneticisidirler.”160 ayeti üstünlükten değil, erke-

158 Muhammed eş-Şerefi, el-İslam ve'l- Hürriyye Sû̂'t-Tefâhüm et-Tarihî, Dımaşk, Dâru Betrâ, 2008, s. 103-105.

159 Nahl, 16/90; Nisa 4/58; Kehf, 18/29; Hûd, 11/113.

160 Nisâ, 4/34. 
ğin yüklendiği aile içi yetkiden, yani kavvam olmaktan bahsetmektedir. Erkeğin kendi güç ve potansiyeline orantılı olarak bazı görevlerle donatılması ve kadının da yine kendi çapına göre bazı görev ve yetkilerle sorumlu tutulması, ğayet fitri ve makul bir durumdur. Üstünlük, cinsler arası değildir. Nihayet boşama yetkisinin erkeğe ait olması da böyledir. Erkek bu yetkisini evlilik aktinde yahut sonrasında karısına verebilir. ${ }^{161}$ Erkek ve kadın karşılıklı haklara sahiptirler. ${ }^{162}$ Zulme uğrayan kadının dini anlamda mahkemeye müracat hakkı, her zaman mevcuttur. ${ }^{163}$

Müslümanın gayr-1 müslime karş1 üstünlüğü hususuna gelecek olursak İslam'da insanlar, renk, ırk, dil, bölge, fakirlik ve zenginlik şeklinde kast ayırımına tabi tutulmamışlardır. İslamda insanlar, insan olma yönleriyle asla haksızlığa uğratılmazlar. Ancak bazı hukuki düzenlemelerde elbette dinin bakış açısı gereği insanlar, iman, küfür şeklinde ayrı inançlarda mütalaa edilmiştir. Hatta bu noktada kafirlerin hepsi aynı konumda değildir. Onlardan Ehl-i Kitap olanlarla, diğerleri aynı olmadığı gibi; Müslümanlara karşı savaşanlarla, savaşmayanlar da aynı değildir. Onlardan kimi zimmi, kimi de müste'men olarak bazı haklara sahiptir. Bu durum, tabiiyet kavramı kapsamında değerlendirilir. ${ }^{164}$

Hürün köleye karşı üstünlüğü, İslami nassları ve onlara dayalı fikhı yanlış bir konuma oturtmaktan kaynaklanan bir anlayışı sergilemektedir. Kölelik İslam'ın bizzat te'sis ettiği bir şey olmayıp daha öncesinde bütün beşeri hukuk ve yapılanmalarda realite olarak bulunmaktayd $1 .{ }^{165}$ İslam, köleliği eski medeniyetlerde ve çağdaşı güçlü devletlerde yerleşmiş ve tabi kabul edilmiş bir konumda bulduğundan onu tek taraflı ve kesin bir kararla kaldırma yönüne gitmemiştir. ${ }^{166}$

İslamda asıl olan hürriyettir. Kölelik ârızidir. Bunun yegane sebebi ise savaştır. Her millet savaşlarda vesair sebeplerle elde ettiği esirleri ya öldürüyor yahut pek zor işlerde kullanıyorlardı. İslamın böyle bir durumda bu müesseseyi tamamen ihmal etmesi düşünülemezdi. ${ }^{167}$

161 Hayreddin Karaman, Mukayeseli İslam Hukuku, İstanbul, İz Yayınc1lık, 9. bs., 2016, 1/358.

162 Bakara, 2/233.

163 M. Koçak (vd.leri), a.g.e., s. 256.

164 Hayreddin Karaman, Mukayeseli İslam Hukuku, 3/216-218.

165 Ahmed Şefik Bey, er-Rıkk fi'l-İslam, mua. Ahmed Zeki, Mısır, Müessesetü'l Hindavi, 2012, s. 15 .

166 M. Akif Aydın-Muhammed Hamidullah, "Köle", İslam Ansiklopedisi, cilt XXVI, İstanbul, TDV İslam Ansiklopedisi Genel Müdürlüğü Yayını, 2002, s. 238.

167 Ömer Nasuhi Bilmen, Hukuki İslamiyye ve Istılahatı Fıkhiyye Kamusu, İstanbul, Bilmen Yay1nevi, 1990, 4/31. 
Her şeyden önce şunu ifade edelim: Hiçbir dinî nassta köle, kınanmış hak ve hukuk açısından geriye itilmiş ikinci derecede bir vatandaş statüsünde görülmemiştir. Aksine köle ve dolayısıyla cariye, İslam toplumunun, hatta Müslüman ailenin bir parçası sayılmış ${ }^{168}$ ve bu kardeşlik ve dostluk muamelesinin bir neticesi olarak bir çoğu, İslamiyet'e girmişlerdir. Birçok meşhur kıraat âlimi ve fakihin kölelerden çıkması, tarihi bir vâkıadır.

Köle azat etmek, Allah'a yaklaştırıcı bir ibadet telakki edilmiştir. Hata ile öldürme, zıhar, yemin vb. kefaretlerde köle azat edilmesi, bir ibadet kabilindendir. Zekatın verilme yerlerinden biri de kölelerin azadıdır. ${ }^{169}$ İslam fikhında hür ve köle arasında kısas ve herhangi bir organı kesme durumunda uygulanacak ceza, bazı fakihlerce ihtilaf konusu olsa da ilgili ayetin umumu ve sahih hadislerle İslami uygulama, bu konuda her ikisinin de aynı konumda olduğu yönündedir. ${ }^{170}$ Ayrıca zina eden evli cariyeye recm cezası yerine yüz celdenin yarısı yani, elli celde uygulanmas $1^{171}$ da kölelere şefkatin ve konumuna uygun adalet ve hakkaniyetin göstergesidir. Aslında İslam dini ve dolayısıyla İslam fikhı, köle hukuku konusunda övülecek bir ayrıcalığa sahiptir. Zira köle, anlatıldığı üzere temelde savaş esiridir. Kur'an, İslami otoriteyi köle konusunda ilk defa savaş esiri olarak alındıklarında onu idam etme ile salıverme arasında serbest bırakmıştır. ${ }^{172}$ Onların esir alındıktan sonra öldürülmeleri caiz olduğu hâlde, öldürülmeyip ve aynı zamanda hapishanelerde çürütülmeden Müslüman bir aile bireyi gibi muamele görmeleri, hangi dinde mevcuttur? Üstelik kölenin evlilikle ilgili hakları açık ayetlerle hüküm altına alınırken; onun, Müslüman bayan olan efendisine karş1 zinetin görünmesi bağlamında mahremleri arasında zikredilmesi, kendisine verilen değeri ifade etmesi açısından ne de önemlidir! ${ }^{173}$

Köleyle ilgili davranışın önemli boyutlarına işaret eden Ahmed Cevdet Paşa'nın şu veciz ifadelerini burada aktarmakta yarar görüyorum: "Müslümanlıkta köle almak, köle olmaktır." ${ }^{174}$

168 Buhari, Itk, 50-51; Müslim, Elfaz, 13-15.

169 Nisâ, 4/92; Maide 5/89; Mücadele, 58/3; Bakara, 2/177; Beled, 90/13; Tevbe, 9/60.

170 Muhammed Ebu Zehra, el-Cerimetü ve'l-'Ukûbetü fi'l-Fıkhı'l-İslamî, el-'Ukûbe, el-Kahire, Dâru'l-Fikri'l-Arabî, 2006, s. 332-337.

171 Nisâ, $4 / 25$.

172 Muhammed, 47/4.

173 Nûr, 2431/.

174 Kamil Miras, Sahihi Buhari Muhtasarı Tecridi Sarih Tercemesi, Ankara, Diyanet Yayınları, 1982, 7/467. 


\section{Sonuç}

Fıkıh ve şeriat kavramları, sözlük ve terimsel anlamlarıyla mülahaza edildiklerinde şeriatın, din ile eş anlamlı olup genellik, sabitlik ve kesinlik özelliklerini taşıdığını ve buna karşılık fikhın, şeriata bağlı olmak şartıyla zaman ve mekanın değişimiyle orantılı olarak ameli konular özelinde ictihad eksenli olduğunu görmekteyiz. Ancak şurası var ki fikıh ya direkt nasstan çıkarım yoluyla yahut ona döndürülecek bir yorum şekliyle elde edilen malumatı ihtiva etmekle tamamen beşeri çıkarımlardan oluşan hukuk ve doktrinlerden farklı bir noktada seyretmektedir. Araştırmamızda görüldüğü üzere fıkıh, ictihadın bir neticesi olarak bazı ihtilafları taşısa da bunlar, delillerden kaynaklandığı müddetçe meşruiyeti zedeleyecek türden sayılmaz. Ayrıca bu tikel ihtilaflar, fikhı bütünsellik açısından şeriattan tamamen ayrı bir kategoride görmemizi gerektirmediğini düşünüyorum. 


\section{Kaynakça}

Ak, Ayhan, İslam Hukuk Felsefesi, 1. bs., İstanbul, Ensar Neşriyat, 2014.

El-Âmidi, Ebü'l-Hasan Seyfeddin Ali b. Muhammed b. Salim, el-İhkam fi Usuli'l-Ahkam, ta. Eş-Şeyh İbrahim el-Acuz, 1. bs., Beyrut, Daru'l-Kütübi'l-İlmiyye, 1985.

Atar, Fahrettin, Fıkıh Usülü, 6. bs., İstanbul, M.Ü. İFAV Yayınları, 2006.

Aydın, M. Akif-Muhammed Hamidullah, "Köle", Islam Ansiklopedisi, cilt XXVI, İstanbul, TDV İslam Ansiklopedisi Genel Müdürlüğü Yayını, 2002.

Ayengin, Tevhid, "Hukuki Dinamizm ve İctihadda İsabet Tartışmaları", Ma'rife, Kiş 2012.

Bilmen, Ömer Nasuhi, Hukuki İslamiyye ve Istılahatı Fıkhiyye Kamusu, İstanbul, Bilmen Yayınevi, 1990.

El-Bûti, Muhammed Said Ramazan, Davabitü'l-Maslaha fi'ş-Şeriati'l-İslamiyye, 4. bs., Dimaşk, Daru'l-Fikir, 2005.

El-Cevziyye, Ebu Abdillah Şemsüddin Muhammed b. Ebî Bekr Eyyüp eş-Şehir bi-İbni'1-Kayyim, I'lamu'l-Muvakkiin An Rabbil Âlemin, tk. Abdurrauf Sad, Beyrut, Daru'l-Ceyl, 1973.

El-Cürcani, Ali b. Muhammed b. Ali, et-Ta'rifat, thk. İbrahim el-Ebyari, 1. bs., Beyrut, Dâru'l-Kitabi'1-Arabi, 1985.

Dalgın, Nihat, “İslam Hukuku ve Evrenselliği”, Mehir, say1 3, 1999.

Ed-Derkâni, Necmüddin Muhammed, et-Telkih Şerhu't-Tenkih li-Sadriş-Şeria, 1. bs., Beyrut, Dâru'l-Kütübi'l-İlmiyye, 2001.

Devellioğlu, Ferit, Osmanlıca Türkçe Ansiklopedi Lügat, 25. bs., Ankara, Aydin Kitabevi, 2008.

Ed-Dihlevi, Şah Veliyullah, thk. Said Ahmed b. Yusuf el-Bâlenburi, Hüccetüllahi'l-Baliğa, 3. bs., Beyrut, Dâru İbn Kesir, 2017.

Ebu Zehra, Muhammed, el-Ahvalu’ş-Şahsiyye, el-Kahire, Daru'l-Fikri'l-Arabi, t.y. hire, Daru'l-Fikri'l-Arabi, 2006.

, el-Cerimetü ve'l- 'Ukûbetü fi'l-Fıkhı'l-İslamî, el-'Ukûbe, el-Ka, Usulu'l-Fıkh, el- Kahire, Dâru'l-Fikril-Arabî, t.y.

Ebu Zehv, Muhammed Muhammed, el-Hadis ve'l-Muhhaddisûn, Beyrut, Daru'l-Kitabi'l-Arabi, 1983. 
Erdoğan, Mehmet, İslam Hukukunda Ahkamın Değişmesi, 8. bs., İstanbul, İFAV Yayınları, 2014. yat, 2015.

, Fıkıh ve Hukuk Terimleri Sözlügü, 5. bs., İstanbul, Ensar Neşri-

El-Ezherî, Ebu Mansur Muhammed b. Ahmed, Mu'cemu Tehzibi'l-Luga, thk. Riyad Zeki Kasım, 1. bs., Beyrut, Dâru'l-Ma'rife, 2001.

El-Fâsi, Allâl, Müfekkiretü'l-Fıkhi'l-İslami ve Mukârenetühü bi'l-Fıkhi'l-Ecnebi, er-Ribat, Müessesetü Allâl Fâsi, t.y.

El-Gazzali, Ebu Hamid b. Muhammed, el-Mustasfâ min İlmi'l-Usûl, thc. Tâha eş-Şeyh, Kahire, el-Mektebetü’t-Tevfikiyye, 2010.

Güler, İlhami, Dine Yeni Yaklaşımlar, 3. bs., Ankara, Ankara Okulu Yayınları, 2016.

El-Hafif, eş-Şeyh Ali, Ahkamu'l-Muamelati'ş-Şer'iyye, Kahire, Dâru'l-Fikri'l-Arabî, t.y.

Halil b. Ahmed, Ebû Abdurrahman Halil b. Ahmed b. Amr Ferahidi, Kitâbu 'lAyn, 2. bs., Beyrut, Dâru İhyâi't-Türâsi'l-Arabi, 2005.

Hammâmi, Nâdir, İslamu'l-Fukahâ, 1. bs., Beyrut, Dâru't-Talia, 2006.

el-Hanbelî, Şakir Beg, Usuûlu'l-Fıkh, 1. bs., Mekke, el-Mektebetü'l-Mekkiyye, 2002.

Hançerlioğlu, Orhan, Felsefe Ansiklopedisi Kavramlar ve Akımlar, 4. bs., İstanbul, Remzi Kitabevi, 2005.

İbnu'l-Esir, Mecdüddin Ebu's-Seâdât el-Mübarek b. Muhammed el-Cezeri, en-Nihâhye fi Garibi'l-Hadis ve'l-Eser, thk. eş-Şeyh Halil Ma'mun Şihâ, 4. bs., Beyrut, Daru'l-Ma'rife, 2011.

İbn Fâris, Ebu'l-Hüseyin Ahmed, Mekâyisu'l-Luga, Beyrut, Dâru İhyai't-Tûrasi'l-Arabi, t.y.

İbn Haldun, Ebu Zeyd Veliyyüddin Abdurrahman b. Muhammed, Mukaddime, Beyrut, Daru'l-Ceyl, t.y.

İbn Rüşd, Muhammed b. Ahmed b.Muhammed b. Ahmed el-Hafid, Bidayetü'l-Müctehid ve Nihayetü'l-Muktasıd, thk. Abdulhalim Mahmud Abdulhamid, 2. bs., el-Kahire, Daru'l-Kütübi'l-İslamiyye, 1983.

İbn Salah, Osman b. Abdirrahman b. Osman el-meşhur bi İbn Salah eşŞehrezûrî, Mukaddimetü İbn Salah fi İlmi 'l-Hadis, thk. Üsame el-Belhi, Beyrut, Dâru'l-Kitabi'l-Arabî, 2005. 
İhmidan, Ziyad Muhammed, Makâsidu'ş şeriati'l İslamiyye, 1. bs., Beyrut, Müessesetü'r Risale, 2008.

İsmail, Şa'ban Muhammed, Tarıhu'l-Teşrii'l-İslamî Mera'hiluhu ve Masadiruhu, 1. bs., el-Kahire, Daru's-Selam, 2010.

El-İzmiri, Süleyman b. Veli b. Resul el-Kırşehri, Hâşiyetü'l-Fazli'l-İzmiri ale 'l-Mir'at, İstanbul, Matba-i Âmire, h.1309.

İzmirli İsmail Hakkı, İlmi-i Hilaf, Sad, Fuat Ateş, Konya, Hüner Yayınevi, 2010 .

El-Kannûcî, S1ddık Han, Ebcedu'l-Ulûm, Beyrut, Dâru'l-Kütübi'l-i̇lmiyye, h.1398.

Karaman, Hayreddin, İslam Hukuk Tarihi, 22. bs., İstanbul, İz Yayınc1lık, 2016. , Mukayeseli İslam Hukuku, 9. bs., İstanbul, İz Yayınc1lı, 2016.

El-Kattan, Menna, Tarihu't-Teşrii 'l-İslamî, 2.bs., Beyrut, Müessesetü'r-Risale, 1982.

Kılıç, Muharrem, "Hukuki Görüş Ayrılıkları (İhtilaf) ve Hilafa Riayet (Mürââtü'l-Hilaf) İlkesi Konusunda Şâtıbi’nin Yaklaşımı”, Marife, yıl 5, sayı 2, Güz 2005.

Koçak, Muhsin- Dalgın, Nihat-Şahin, Osman, İslam Hukuku: İslam Hukukuna Giriş, Aile Hukuku, Miras ve Ceza Hukuku, 3. bs., İstanbul, Ensar Neşriyat, 2016.

El-Kurtubî, Ebu Abdillah Muhammed b. Ahmed el- Ensari, el Cami'li-Ahkami'l-Kur'an, 1. bs., Beyrut, Daru'l-Kütübi'l-İlmiyye, 1988.

El-Mahallavî, Muhammed Abdurrahman Îyd, Teshîlu'l-Vusûl ila İlmi 'l-Usûl, Misır, Matbaatu Mustafa el- Baba el-Halebî ve Evladuhu, 1341.

Miras, Kamil, Sahihi Buhari Muhtasarı Tecridi Sarih Tercemesi, Ankara, Diyanet Yayınlar1, 1982.

Mütercim Asım Efendi, el-Okyanusü'l-Basit fi Tercümeti Kamusi'l-Muhit, el-Kostantiniyye (İstanbul), Matbai Âmire, t.y.

Er-Rağıb el-İsfahani, Ebü'l-Kâsım Hüseyin b. Muhammed b. Mufaddal, Müfredâtü Elfazi'l-Kur'an, thk. Safvan Adnan Davûdi, 4. bs., Beyrut, ed-Daru'ş-Şâmiyye, 2009.

Er-Razi, Fahreddin Muhammed b. Ömer b. el-Hüseyin, el-Mahsul fi-İlmi Usuli'l-Fıkh, 1. bs., Beyrut, Dârü'l-Kütübi'l-i̇lmiyye, 1988. 
Er-Razi, Muhammed b. Ebi Bekr b. Abdilkadir, Muhtaru's-Sihah, 7. bs., el-Kahire, el-Matbaatü'l-Emiriyye, t.y.

Sayis, Muhammed Ali (vd. leri), Tefsiru Ayâti'l-Ahkâm, ta. Hasen es-Semâhi Süveydân, 6. bs., Beyrut, Dâru İbn Kesir, 2012.

Es-Suyuti, Celaleddin Abdurrahman, , Lübabün-Nukûl fi Esbabin-Nüzul, thk. Muahmmed el-Fadili, Beyrut, el-Mektebetü'l-Asriyye, 2006.

Es-Sübkî, Kadı'l-Kudât Tacüddin Abdulvehhab b. Ali b. Abdülkafi b. Ali b.Temmam b. Yusuf, Cem 'u'l-Cevami' fi Usûli'l-Fıkh, thk. Abdulmin'im Halil İbrahim, 2. bs., Beyrut, Dâru'l-Kütübi'l-İlmiyye, 2002.

Eş-Şatıbî, İbrahim b. Musa el-Lahmi el-Gırnati, el-Muvafakât fi Usûli'ş-Şeria, thk. Abdullah Diraz, 2. bs., Beyrut, Daru'l-Ma'rife, 1997.

Şefik Bey, Ahmed, er-Rıkk fi'l-İslam, mua. Ahmed Zeki, Mısır, Müessesetü'l-Hindavi, 2012.

Eş-Şelebi, Muhammed Mustafa, el-Medhal fi't-Ta'rif bi'l-Fılkhi'l-İslami ve Kavaidu'l-Milkiyye ve'l-Ukûd Fihi, Beyrut, Dâru'n-Nahda, 1985.

Şeltut, Mahmud Muhammed - Sayis, Muhammed Ali, Mukarenetu'l-Mezahib fi'l-Fıkh, 1. bs., İstanbul, Mektebetu'l-İrşad, 2016.

Eş-Şerefi, Abdulmecid, el-İslam Beyne'r-Risale ve 't-Tarih, 1. bs., Beyrut, Daru't-Talia, 2001.

Eş-Şerefi, Muhammed, el-İslam ve'l- Hürriyye Sû̂'t-Tefâhüm et-Tarihi, D1maşk, Dâru Betrâ, 2008.

Eş-Şevkâni, Muhammed b. Ali b. Muhammed, Neylü'l-Evtâr Şerhu Munteka'l-Ahbar min Ahadisi Seyyi'l-Ahyar, thk. Isameddin Sabbabeti, el-Kahire, Daru'l-Hadis, 2005.

Şeyh Muhammed, Alya, Silatu's-Sünneti bi'l-Kur'an ve Reddu Şubuhat Muasıra, 1. bs., Dımaşk, Daru'l-Feyha, 2000.

Eş-Şınkıtî, Muhammed el-Emin b.Muhammed el-Muhtar, Müzekkiretün $f_{i}$ Usuli'l-Fıkh, 5. bs., el-Medinetü'l-Münevvere, Mektebetü'l-Ulumi ve'l-Hikem, 2001.

Et-Tûfi, Ebu'r-Rebi' Necmeddin Süleyman b. Abdülkavi b. Abdulkerim b. Said, Risaletün fi Riayeti'l-Maslaha, thk. Ahmed Abdurrahim es- Sayih, 1. bs. y.y., ed-Daru'l-Misriyye el-Lübnaniyye, 1993.

Türcan, Talip, "İslamın Evrensel Hukuk Düşüncesine Katkıları", III. Kutlu Doğum Seтроzуuтu : Tebliğler, 2000. 
, "Şeriat", İslam Ansiklopedisi, cilt XXXVIII, İstanbul, TDV İslam Ansiklopedisi Genel Müdürlüğü Yayını, 2010.

Uslu, Rifat, "İslam Hukukunda Kolayl1k Prensibi”, Uluslararası Sosyal Araştırmalar Dergisi (The Journol Of International Social Research), cilt VIII, say1 36, 2015.

El-Vahidî, Ebu'l Hasen Ali b. Ahmed en-Nisaburî, Esbabu'n-Nüzul, Beyrut, el-Mektebetü'l-Asriyye, 2005.

Wensinck, A.J., Concordance Et Indices DE LA Tradition Musulmane, Leden, E. J. Brell, 1955.

Yaman, Ahmet - Çalış, Halit, İslam Hukukuna Giriş, 10. bs., İstanbul, M.Ü. İFAV Yayınları, 2015.

Yazır, Elmalılı Muhammed Hamdi, Hak Dini Kur'an Dili, İstanbul, Eser Yayınevi, t.y.

Zeydan, Abdulkerim, el-Medhal li-Diraseti'ş-Şeriati'l-İslamiyye, 1. bs., Beyrut, Müessesetü'r-Risale Naşirun, 2013.

,el-Vecîz fi Şerhi'l-Kavaidi'l-Fikhiyye fi'ş-Şeriati'l-İslamiyye, 2. bs., Beyrut, Müsessesetü'r-Risale, 2014. şirûn, 2004. , el-Veciz fi Usûli'l-Fıkh, 1. bs., Beyrut, Müessestü'r-Risale en-Na- 
